\title{
Territories of Faith: 1000 Years of Landscape Multifunctionality in Santa Mariña de Augas Santas (NW Spain)
}

\author{
Cruz Ferro-Vázquez ${ }^{1, *(1)}$, Rebeca Blanco-Rotea ${ }^{2}$, Jorge Sanjurjo-Sánchez ${ }^{3}{ }^{\oplus}$, Sonia García-Rodríguez ${ }^{4}(\mathbb{D}$ \\ and Marco V. García Quintela ${ }^{2}$ \\ 1 Interdisciplinary Center for Archaeology and Evolution of Human Behaviour (ICArEHB), \\ Campus de Gambelas, Universidade do Algarve, 8005-139 Faro, Portugal \\ 2 Departamento de Historia, Universidade de Santiago de Compostela, 15782 Santiago, Spain; \\ rebeca.blanco.rotea@usc.es (R.B.-R.); marco.garcia.quintela@usc.es (M.V.G.Q.) \\ 3 Instituto Universitario de Xeoloxía "Isidro Parga Pondal", Universidade de A Coruña, 15071 A Coruña, Spain; \\ jorge.sanjurjo.sanchez@udc.es \\ 4 Independent Researcher, 36003 Pontevedra, Spain; sonia.garcia.ro@gmail.com \\ * Correspondence: mcvazquez@ualg.pt or cruz.ferro@gmail.com
}

check for

updates

Citation: Ferro-Vázquez, C.;

Blanco-Rotea, R.; Sanjurjo-Sánchez, J.;

García-Rodríguez, S.; García Quintela,

M.V. Territories of Faith: 1000 Years of

Landscape Multifunctionality in

Santa Mariña de Augas Santas (NW

Spain). Land 2021, 10, 992. https://

doi.org/10.3390/land10090992

Academic Editor:

Alexandru-Ionuţ Petrişor

Received: 5 August 2021

Accepted: 16 September 2021

Published: 21 September 2021

Publisher's Note: MDPI stays neutral with regard to jurisdictional claims in published maps and institutional affiliations.

Copyright: (c) 2021 by the authors. Licensee MDPI, Basel, Switzerland. This article is an open access article distributed under the terms and conditions of the Creative Commons Attribution (CC BY) license (https:// creativecommons.org/licenses/by/ $4.0 /)$

\begin{abstract}
Landscape multifunctionality is increasingly recognized as an important aspect in sustainability and developmental debates. Yet, how and why a multifunctional landscape configuration develops over time has not been sufficiently studied. Here we present the geoarchaeological investigation of the Santa Mariña de Augas Santas site, in northwestern Spain. We focus on the role of religious practice, and of its interplay with productive strategies, in landscape transformation. A geochemical, mineralogical, and geochronological characterization of the pedo-sedimentary record (including XRF, EA-IRMS, XRD, OSL and 14C measurements) allowed to characterize catchment scale sedimentation processes in relation to agricultural activities. The geographical and chronological coincidence of production functions with documented religious activities demonstrate that both aspects shared geographical spaces during the last millennium. Current landscape multifunctionality at Santa Mariña is thus not the final outcome of a specific evolution, but an essential aspect of traditional land use strategies through history and a driver of change. This work highlights the need of a long-term study of the processes of landscape configuration when assessing the sustainability of traditional productive systems.
\end{abstract}

Keywords: multifunctionality; landscape change; religion; agriculture; pedo-sedimentary record

\section{Introduction}

Since its first appearance in scientific literature in the 1980s [1,2], the concept of landscape multifunctionality has escalated positions in the international developmental agendas, and is today many times presented as a cornerstone in modern land planning strategies for sustainability [3-5]. Multifunctional landscapes have been identified and studied in rural settings, frequently in relation to traditional agricultural activities [6]. This is probably the reason why the concept of landscape multifunctionality has been used arbitrarily for both characterizing the diversity of agriculture-related land uses in a territory and for describing the landscape itself [7]. The latter view includes agricultural production as just one of several landscape functions, and is the view adopted in this work: here we consider multifunctionality as an emergent property [8] that consists in the capacity of a territory for serving to more than one of the four landscape functions: provision, regulation, habitat, and cultural [9-11].

While the provision function has been widely studied, and its interlinks with the regulation and habitat functions thoroughly assessed [12-14], the contribution of cultural, non-commodity aspects to landscape configuration has not received the same attention. As an important facet of the landscape cultural function, rituals and religious practice have 
been, and are still today, key drivers of land management [15-17], both as a spontaneous expression of society's spiritual concerns and used in an instrumental way by elites and powers. However, little work has been done on the assessment of the repercussions of religious practice in landscape evolution, and on the long term landscape configuration legacies brought by the interactions between religion and provision functions. Thus, an essential part of the factors and processes through which multifunctionality is adopted as a land use strategy has not been fully studied. This impedes a complete understanding of multifunctionality itself, and limits the possibilities of success of developmental interventions towards its implementation in modern settings.

Here we address these aspects through the study of the area of Santa Mariña de Augas Santas (hereinafter, Santa Mariña), located in Galicia (NW Spain). There, a series of Christian worship spaces, which have been identified with different phases of the martyrdom of Mariña [18,19], coexist with agricultural and forestry activities. Three out of the four ecosystem functions outlined in the Millennium Ecosystem Assessment [20]: the supporting, provisioning and cultural functions are unequivocally represented in today's Santa Mariña, which consequently qualifies as a multifunctional landscape. We hypothesize that the present multifunctional configuration has its origins in the spread and consolidation of Christianity and its socio-economic and political structures after the Roman Period, which acted on and modified productive strategies rooted in previous cultures. Its diachronic investigation and, in particular, the long term interlinks between religious and subsistence practices and their effects in landscape evolution are therefore required for understanding present landscape features [21,22].

In order to appraise this interplay and to assess the contribution of the different factors and processes, here we address the geoarchaeological characterization of one of the more important worship spaces of Santa Mariña, through the combination of the geochemical study of the pedo-sedimentary record with already available historical, archaeological, and documentary information. This kind of approach has been successfully used to characterize landscape configuration processes and land use change in anthropically modified environments [23-26], by taking advantage of the capacity of soils and sedimentary sequences for storing the signals of human activities [27].

This diachronic site-scale study of the development of multifunctionality is not intended to provide a detailed reconstruction of landscape evolution of the Santa Mariña area. It instead aims to deliver data on its history and the factors that contributed to its multifunctional configuration. In addition, this work has the more ambitious goal of providing knowledge that can contribute to understanding the processes that shaped multifunctional landscapes elsewhere. The specific objectives are: (i) appraising the transformations of the Forno da Santa enclave through time, (ii) linking this evolution with the history of the religious buildings at this site, and (iii) getting insight on the processes that led to the current multifunctional configuration, with particular attention to the consolidation of the Christianism in NW Spain.

\section{Materials and Methods}

\subsection{Characteristics of the Site and Previous Research}

The study site is located in Armeá which is a small village of the Santa Mariña de Augas Santas parish, in Galicia, NW Spain (Figure 1a,b). Legend has it that, around the 2nd century AD, a teenager called Mariña was asked to renounce her Christian faith and accept the proposals of a Roman governor. She refused and, for that reason, she was tortured and killed. Her martyrdom has then been materialized by the construction of different heritage elements in specific spaces [28]. It outstands among these places the Forno da Santa, an Iron Age sauna reinterpreted as the crematory oven were Santa Mariña was supposed to have been burnt to death, should the intervention of Saint Peter would not have saved her, which was later transformed in basilica, the Basilica de la Ascensión (Figure 1b). Another relevant location is the place where the Saint was finally killed, next to the current big Romanesque parish church. There, sacred water is said to 
have sprung from the three exact places where the head of Mariña touched the ground when she was beheaded-this explains the name "Augas Santas" (Holy Waters). Water continues to flow today and there are thousands of believers who come to drink and wash in these miraculous waters, to which healing powers are attributed as acknowledged in documentary sources. Local accounts of Mariña's martyrdom have been attested since the 16th century [29] (pp. 384-385) and are preserved by the local community by word of mouth (see examples of oral testimonies in the video-documentary "Lume na Auga" available at http:/ / santamarinadeaugassantas.com/, accessed on 1 August 2021). The legend of Santa Mariña and related historical, social and ethnographical importance has been long a matter of interest among researchers [30-35]. The myth itself has been addressed by historical research and through the study of documentary sources [18,36,37].
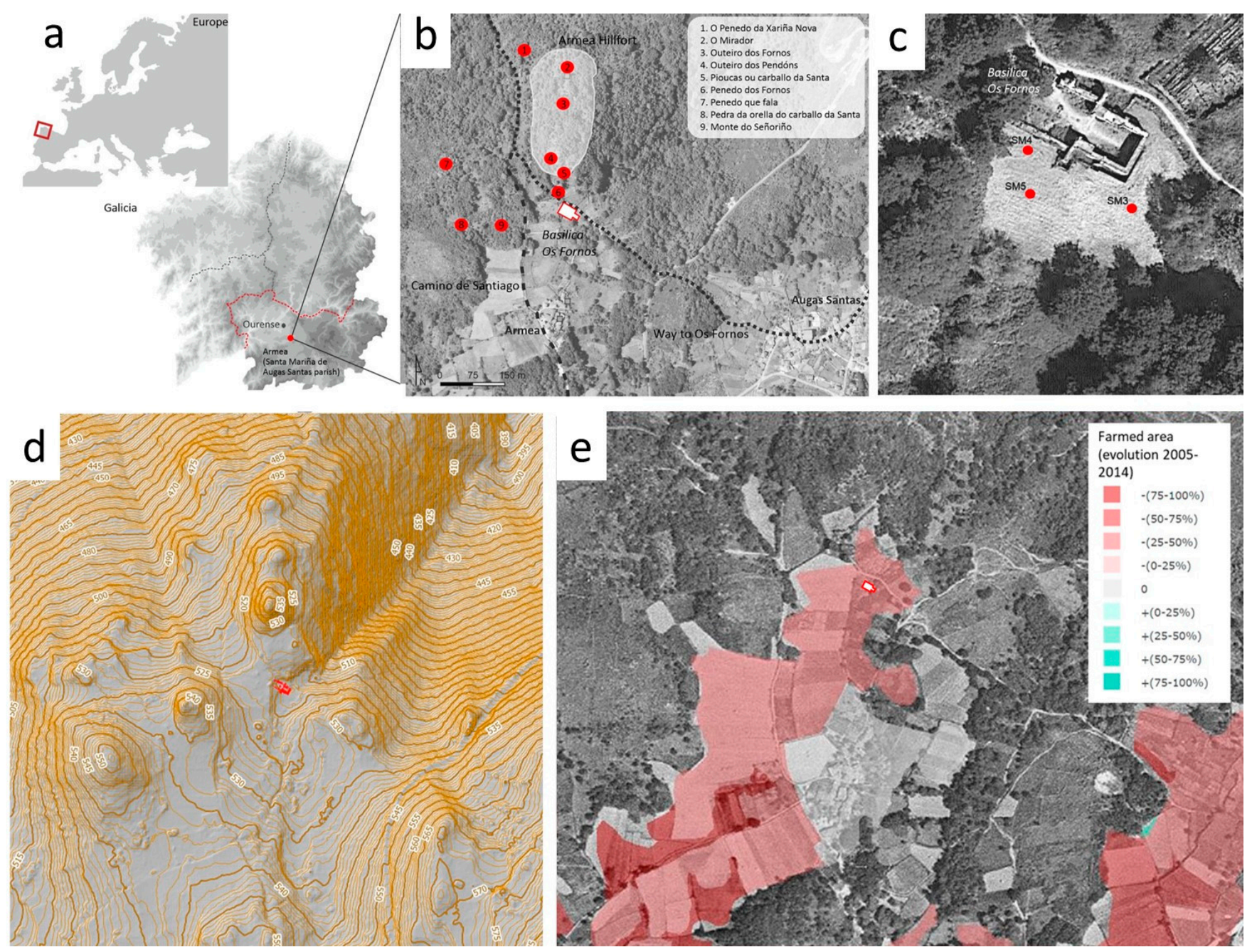

Figure 1. (a) Geographical location of Santa Mariña; (b) orthoimage of the site, indicating the location of the Basilica and other symbolic landmarks related to Santa Mariña myth; (c) position of the sampled cores; the SM3 core was selected for geochemical study because of its higher potential for storing paleoenvironmental and geoarchaeological information; (d) topographic setting of Santa Mariña and surroundings. Present day land use is still a combination of agricultural, forestry, habitational, and worship spaces, although the farmed area has decreased during the last decades, in favour of forest exploitation or secondary deciduous forest communities. (e) shows the evolution of the farmed land between 2005 and 2014 (shaded area) with the background photograph showing the extension of cultivated land in the 1950s (data from the Spanish system of land use observation-SIOSE 2014—and published online by Xunta de Galicia: http: / / mapas.xunta.gal/visores / ocupaciondosolo/ accessed 13 September 2021).

This work's specific sampling location is the thalweg where the Forno da SantaBasílica de la Ascensión—sits (Figure 2). It is surrounded by gentle slopes that are today 
terraced and which have been historically under agricultural or forest use, although some of them have not been exploited in the last decades and are nowadays under secondary deciduous forest vegetation. The lithology of the area is granitic, and current climate is mild and humid (Csb in Koppen classification), with an annual temperature of $13.1^{\circ} \mathrm{C}$ and a mean accumulated rainfall of $1063 \mathrm{~mm}$ per year, of which the largest part falls in winter.
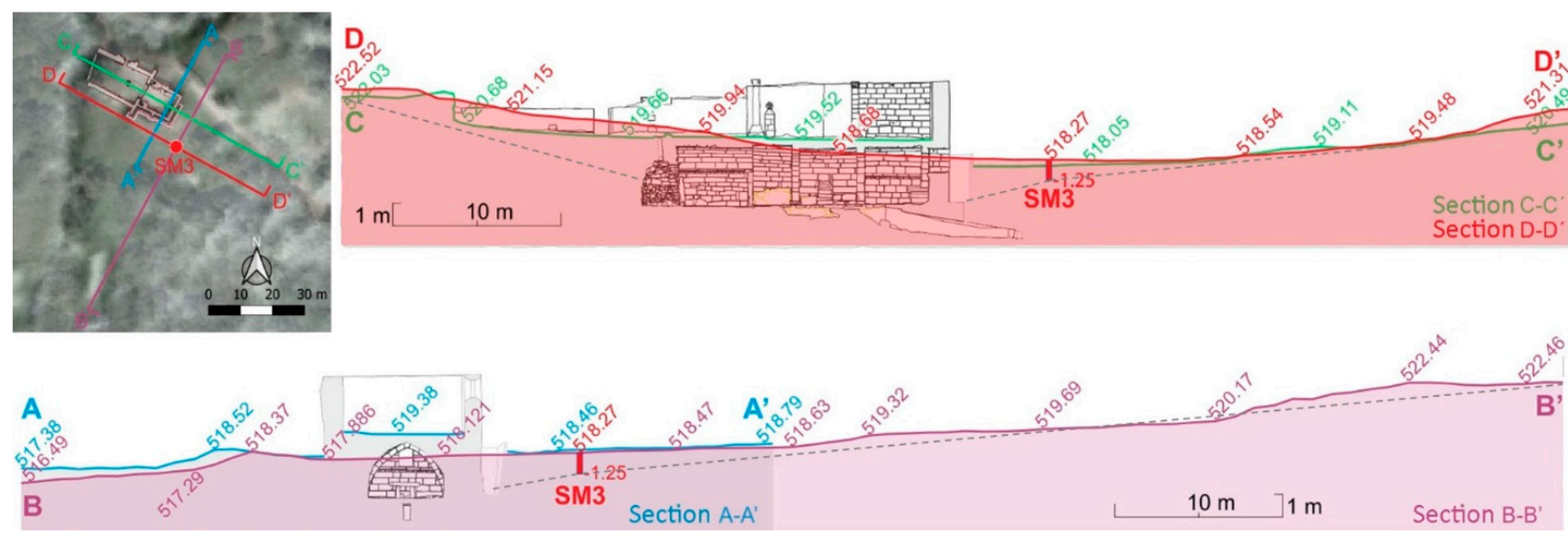

Figure 2. Topographic cross sections showing the position and depth of the core, and the current soil surface, of the Basilica and the Forno. The dashed lines show a hypothetical land surface previous to the modifications of topography at the site.

The transformations of the buildings that relate to the martyrdom and posterior worship have been investigated through archaeological methods. Of special interest for this work are the stratigraphic studies of the walls of the crypt and the Basílica de la Ascensión [19], the study of a singular group of over 100 medieval votive jars [38], and the archaeometric characterization and OSL dating of mortars [39], which attested the transformation and reuse of architecture through time and its relationship to the spread of the myth of Santa Mariña. In addition, dwelling structures from the 1st century AD have been identified and excavated in two sites nearby Santa Mariña in recent years [40-42].

\subsection{Sampling and Sample Pretreatment}

Three sediment cores were taken in duplicate at three points of the terrace in which the Basilica is located (SM3, SM4, and SM5, Figure 1d). They were chosen for allowing the characterization of the processes leading to the infilling of the thalweg in relation to the history of construction and reform of the religious buildings. The cores were collected in black polyethylene tubes using a ROLATEC ML-76A (Figure 1c). The depth of the cores was determined by the presence of hard rock or the aquitard.

The cores were opened in the laboratory under red light, for preserving the samples from receiving daylight. After the visual inspection and macromorphological characterization description of the cores, SM3 was chosen for further geochemical analysis, as it showed the largest potential for providing paleoenvironmental information at sufficient resolution.

The SM3 core spans from current soil surface to the contact with hard rock at $125 \mathrm{~cm}$ of depth (Figure 2). Below $100 \mathrm{~cm}$ of depth, the core shows signals of periodic waterlogging and has a coarser texture than the samples above $100 \mathrm{~cm}$. The upper part of the sequence $(0-100 \mathrm{~cm})$ shows morphologies consistent with a more advanced pedogenesis, with finer texture and more developed aggregation and structure.

The core was sliced into 26 samples of $5 \mathrm{~cm}$ or thinner, respecting the observed morphological and pedogenetic discontinuities. The samples were air-dried and sieved through a mesh of $2 \mathrm{~mm}$ for separating the fine earth fraction, thus removing gravel and large vegetal remains. Although small fragments of charcoal were observed during the visual inspection of the core, in particular in its deepest section, their mechanical separation was not possible because they were highly degraded and brittle, and only a few millimetric 
fragments were picked manually. An aliquot of each sample was finely ground $(<50 \mu \mathrm{m})$ for their multiproxy geochemical analysis.

\subsection{Geochemical Characterization}

Soil acidity was measured in an aqueous suspension of sediment [43] and in a $1 \mathrm{M} \mathrm{KCl}$ solution [44]. The content of $\mathrm{C}$ and $\mathrm{N}$ and the relative abundance of their stable isotopes $\left({ }^{13} \mathrm{C}\right.$ and $\left.{ }^{15} \mathrm{~N}\right)$ were measured using a FlashEA2000 HT CHNS-O (ThermoFisher Scientific) coupled to a Deltav Advantage mass spectrometer. The total $\mathrm{C}$ is considered equivalent to organic $\mathrm{C}$ due the non-calcareous nature of the local lithology. The abundance of ${ }^{13} \mathrm{C}$ and ${ }^{15} \mathrm{~N}$ are expressed as $\delta^{13} \mathrm{C}$ and $\delta^{15} \mathrm{~N}$, in relation to the abundance of ${ }^{13} \mathrm{C}$ of the Pee Dee Belemnite fossil and of ${ }^{15} \mathrm{~N}$ in atmospheric air, respectively.

The concentration of major, minor, and trace elements was measured in the milled samples by energy dispersion $\mathrm{X}$-ray fluorescence, and the mineralogical composition was characterized by crystalline powder X-ray diffraction, both at the RIAIDT facilities of the University of Santiago de Compostela. The crystalline phases were identified using the HighScore Plus V3.0d software.

\subsection{Chronological Framework}

\subsubsection{Optically Stimulated Luminescence (OSL) Dating}

Five samples were taken from the core under subdued red light in the luminescence lab of the University of Coruña. Coarse quartz grains (180-250 $\mu \mathrm{m})$ were obtained from the samples through the procedures described in Viveen et al. [45]. The obtained quartz grains were investigated with infrared (IR) stimulation to ensure that feldspars were absent and multi-grain quartz aliquots measured by OSL in a Risø DA-15 TL/OSL reader, equipped with blue light-emitting diodes (LEDs).

Multi-grain quartz aliquots of $1 \mathrm{~mm}$ diameter containing ca. 50 grains [46] were mounted and measured in an automated Risø DA-15 TL/OSL reader, equipped with blue light-emitting diodes (LEDs). OSL signals were recorded with a coupled 9235QA photomultiplier tube (PMT) using an optical $6 \mathrm{~mm}$-thick Hoya U-340 filter placed between the aliquots and the PMT. To irradiate the samples, beta doses were used, using a 90Sr/90Y source which provided a dose rate of $0.120 \pm 0.003 \mathrm{~Gy} \mathrm{~s}^{-1}$.

To estimate the equivalent doses (De), the blue-OSL (BL-OSL) single-aliquot regenerative dose (SAR) protocol was used $[47,48]$. In spite of the reduced sample size, we have obtained a high number of accepted aliquots (around 30), except for the sample at $17.5 \mathrm{~cm}$. Aliquots were stimulated for $40 \mathrm{~s}$ at $125^{\circ} \mathrm{C}$, using the first $0.4 \mathrm{~s}$ to measure OSL and the last $4 \mathrm{~s}$ for background subtraction. Previously, preheat tests (from $180^{\circ} \mathrm{C}$ to $280^{\circ} \mathrm{C}$ ) were conducted. Dose recovery tests were also performed for all samples on bleached aliquots [48] after irradiation with beta doses similar to the assessed De. Thermal transfer tests [49] were also performed for all samples and showed no transfer of charge. Quartz grains showed bright signals with a high signal/background ratio and good signal regeneration by beta irradiation. This is probably correlated with the very high dose rates. The dispersion of the De had a normal non-skewed statistical distribution with low overdispersion of the mean of the Central Age Model (8.3-17.4\%) for all samples but the one at $17.5 \mathrm{~cm}$ depth (Table 1). Recovery dose test provided recovery ratios between 0.9 and 0.1 with very low overdispersion values $(<5 \%)$. This resulted in a bright and fast quartz signals which, together with the De distribution of aliquots indicates no evidence of partial bleaching or of other biases in these samples [50]. The sample at $17.5 \mathrm{~cm}$ of depth shows, in contrast, a skewed distribution and an overdispersion value of $62.13 \%$. For this sample, the Minimum Age Model was used to get the OSL age [51]. The good quality of the OSL results is further supported by the stratigraphic consistency of the obtained ages [51]. 


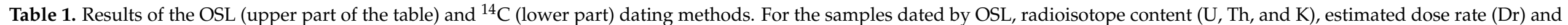

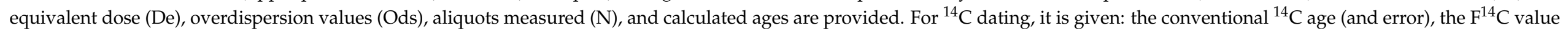
(and error), the calibration probability ranges, the relative area for each interval, and the age calculated by the age-depth model.

\begin{tabular}{|c|c|c|c|c|c|c|c|c|c|c|c|}
\hline Sample & Method & Depth (cm) & $\begin{array}{c}\mathrm{U} \\
\left(\mathrm{mg} \mathrm{kg}^{-1}\right)\end{array}$ & $\begin{array}{c}\text { Th } \\
\left(\mathrm{mg} \mathrm{kg}^{-1}\right)\end{array}$ & $\begin{array}{c}K \\
(\%)\end{array}$ & $\begin{array}{c}\text { Dr } \\
\left(\mathrm{mGy} \mathrm{a}^{-1}\right)\end{array}$ & $\mathbf{N}$ & Ods (\%) & $\begin{array}{l}\text { De } \\
\text { (Gy) }\end{array}$ & Age (y) & Age AD \\
\hline SM3-01 & OSL & 120.5 & $7.94 \pm 0.16$ & $10.60 \pm 0.21$ & $5.06 \pm 0.05$ & $7.17 \pm 0.23$ & 31 & $8 \pm 3$ & $6.18 \pm 0.23$ & $861 \pm 43$ & $1152 \pm 13$ \\
\hline SM3-06 & OSL & 102.5 & $7.75 \pm 0.16$ & $11.95 \pm 0.24$ & $4.98 \pm 0.05$ & $7.10 \pm 0.23$ & 30 & $9 \pm 3$ & $5.55 \pm 0.22$ & $781 \pm 40$ & $1233 \pm 10$ \\
\hline SM3-20 & OSL & 32.5 & $6.86 \pm 0.13$ & $11.20 \pm 0.22$ & $4.81 \pm 0.05$ & $8.04 \pm 0.23$ & 29 & $17 \pm 4$ & $3.00 \pm 0.15$ & $374 \pm 22$ & $1640 \pm 22$ \\
\hline SM3-23 & OSL & 17.5 & $11.2 \pm 0.22$ & $15.85 \pm 0.33$ & $4.65 \pm 0.05$ & $9.02 \pm 0.23$ & 20 & $62 \pm 13$ & $0.46 \pm 0.08$ & $51 \pm 9$ & $1963 \pm 9$ \\
\hline $\begin{array}{c}\text { Sample } \\
\text { (Lab Code) }\end{array}$ & Method & Depth (cm) & ${ }^{14} \mathrm{C}$ & \pm & $F^{14} C$ & \pm & \multicolumn{3}{|c|}{ Calibration range $(2 \sigma)$} & $\begin{array}{c}\text { Relative } \\
\text { area }\end{array}$ & $\begin{array}{l}\text { Cal Age } \\
(\mathrm{AD} / \mathrm{BC})\end{array}$ \\
\hline $\begin{array}{c}\text { SM3-07 } \\
\text { (Beta- } \\
\text { 376756) }\end{array}$ & ${ }^{14} \mathrm{C}$-AMS & 97.5 & 830 & 30 & 0.902 & 0.003 & \multicolumn{3}{|c|}{ Cal AD 1165 to 1265 (Cal BP 785 to 685 ) } & 1.00 & 1192 \\
\hline
\end{tabular}


We assumed secular equilibrium in the $\mathrm{U}$ and Th decay chains, so we used the conversion factors of Guerin et al. [52]. The alpha dose was ignored, and the beta dose corrected [53]. The cosmic dose rates were calculated according to Prescott and Hutton [54]. The content in K, U, and Th in bulk samples was analyzed by X-ray Fluorescence Spectroscopy and Mass Spectrometry with Inductive Coupling Plasma (ICP-MS). The high radioisotope activity concentration observed in all the samples is frequent in granite rocks of the NW of the Iberian Peninsula [55] where values of $U$ and Th are high when compared to the average values considered for these rocks [56,57], resulting in high rates of terrestrial gamma radiation [58]. Similar dose rates have been observed in samples dated by OSL for sediments of the same area in previous studies [39,59]. In that sediments, no disequilibrium was observed, despite some of them corresponded to fluvial samples, and radioisotope contents are close to the same of granites of the area. The samples studied in this work are siliciclastic and of local origin, and provided a similar radioisotope content than the granite source rocks [39].

The water content and water saturation of the samples were assessed in the laboratory. The average water content was estimated considering these values and the depth of the samples in the core.

The results of the OSL dating are provided in Table 1 and details on the analytical parameters in Figure S1.

\subsection{2. ${ }^{14} \mathrm{C}$ Dating}

The ${ }^{14} \mathrm{C}$ content of charcoals of millimetric size manually separated from the sample at 95-100 cm of depth 100 was measured. The pre-treatment consisted in washing the sample with hydrochloric acid previous to graphitization and analysis by AMS. The obtained ${ }^{14} \mathrm{C}$ content was calibrated using the IntCal20 curve [60]. Following the recommendations on reporting of ${ }^{14} \mathrm{C}$ activity levels from Reimer et al. [61], conventional ${ }^{14} \mathrm{C}$ ages, $\mathrm{F}^{14} \mathrm{C}$ values, calibrated age ranges, and probabilities for each range are given in Table 1.

\subsection{Data Handling}

The statistical analyses were carried out using the SPSS20 software package. The Pearson's correlation coefficient ( $r$ ) was used to measure the linear association between variables. Scatter plots were examined for evidence of non-linear associations, heteroscedasticity and non-homogeneous groups.

The geochemical data were transformed to $\mathrm{z}$ scores before their statistical analysis, in order to provide average centering and avoid scale effects. A principal component analysis $\left(\mathrm{PCA}_{\mathrm{GEO}}\right)$ was carried out of the transformed data matrix with the aim of reducing the dimensionality of the dataset and summarizing the variability in a few components [62]. A Varimax rotation was used, in order to maximize the loadings of the variables on the extracted components. The PCs with an eigenvalue $>1$ were retained and variable loadings higher of 0.5 or lower than -0.5 are considered relevant for each PC [63].

A second PCA with Varimax rotation was performed on the transposed data matrix (samples in columns and variables in rows) of X-ray diffraction results (PCAXRD). The

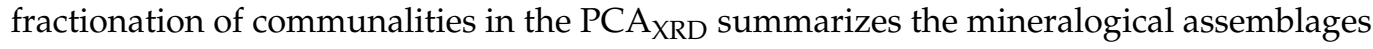
in each sample, and allows for the comparison of samples in terms of how much (in percentage) they are affected by each one of the components.

The chronological framework was built through the calculation of an age-depth model using Clam [64], including all the five OSL and one ${ }^{14} \mathrm{C}$ date, and assigning to the top of the core the date of sampling. The best fit of the model was obtained with linear interpolation. From the depth variation of geochemical composition, two possible changes of sedimentological regime have been inferred, one at $100 \mathrm{~cm}$ and other at $30 \mathrm{~cm}$ of depth, which could indicate regressive site formation events (erosion of previously deposited materials) and consequent chronological hiatuses. At $100 \mathrm{~cm}$, however, since the post quem and ante quem dates for the discontinuity are statistically equal (Table 1), it is considered that there is no chronological hiatus, and the geochemical change at this depth 
is attributed to the seasonal hydromorphic conditions that affect the bottom part of the core. In contrast, the change in the overall composition of the core at $30 \mathrm{~cm}$ cannot be attributed to hydrological conditions, and is thus interpreted as a sedimentological hiatus. This has been included as a parameter for the calculation of the age-depth model.

The results from both PCA (scores of PCA $\mathrm{GEO}_{\mathrm{GEO}}$ and loadings of PCAXRD) were used as entry variables of an unsupervised hierarchical Cluster Analysis (CA), in order to group the samples according to their geochemical composition, with no pre-defined class assignments and without including any chronological data. The calculations were done using the Ward method with square Euclidean distances. The resultant grouping was then put into relation with the results of the age-depth model for dividing the sequence in chronological periods and for calculating the average sediment accumulation rates $\left(\mathrm{cm} \mathrm{y}^{-1}\right)$ for each period.

\section{Results and Discussion}

\subsection{Factors of Formation of the Sedimentary Record}

The database of raw geochemical results is given in Table S1. Briefly, the core shows acid $\mathrm{pH}(\mathrm{pHw}=5.0-6.1)$ that increase with depth, and $\mathrm{pHk}$ lower than $\mathrm{pHw}$ values. The amount of $C$ decreases with depth from $94 \mathrm{~g} \mathrm{~kg}^{-1}$ in the surface of the soil to $6.1 \mathrm{gr}$ $\mathrm{kg}^{-1}$ at $60 \mathrm{~cm}$ and then increases slightly to keep fairly constant values $\left(8.1 \mathrm{~g} \mathrm{~kg}^{-1} \pm 1.1\right)$ until the bottom of the sequence. The amount of $\mathrm{N}$ is highly correlated with $\mathrm{C}$ content $(\mathrm{r}=0.99, p<0.001)$ and varies between $0.6-9.0 \mathrm{~g} \mathrm{~kg}^{-1}$. From these numbers, the $\mathrm{C} / \mathrm{N}$ ratio is low in the entire sequence (8.7-14.5) and shows a general trend to increase with depth. The abundance of $\delta^{13} \mathrm{C}$ varies between $-28.2 \%$ and $-26.0 \%$, following $C$ content $(\mathrm{r}=0.99, p<0.001)$. The $\delta^{15} \mathrm{~N}$ values vary in the range $6.8-8.4 \%$ and show a general trend to decrease with depth $(\mathrm{r}=0.84, p<0.001)$.

The elemental composition of the core reflects its granitic lithology (Table S1), being Si the most abundant element (22.7-32.8\%), followed by $\mathrm{Al}(8.1-12.7 \%)$ and $\mathrm{Fe}(1.5-3.8 \%)$. Relevant amounts of $P$ are detected in the bottom part of the soil $\left(2.4 \mathrm{~g} \mathrm{~kg}^{-1}\right.$ at $\left.110 \mathrm{~cm}\right)$, and of $S$ in the upper part $\left(0.8-2.3 \mathrm{~g} \mathrm{~kg}^{-1}\right.$ in the upper $\left.25 \mathrm{~cm}\right)$. The $S$ contents covariate with $C$ abundance $(r=0.96, p<0.001)$.

The PCA of geochemical results $\left(\mathrm{PC}_{\mathrm{GEO}}\right.$ ) has extracted four principal components (PC) which explain $84.7 \%$ of the total variance (see Table S2 for more details). The first and second principal components ( $\mathrm{PC} 1_{\mathrm{GEO}}$ and 2$)$ account for organic matter dynamics. $\mathrm{PC} 1_{\mathrm{GEO}}(35.8 \%$ of the variance) is linked to the abundance of organic matter and its related elements: C, N, Br, S, Zn and Ti have positive loadings in $\mathrm{PC} 1_{\mathrm{GEO}}$, while $\delta^{13} \mathrm{C}, \mathrm{K}$, and $\mathrm{Sr}$ abundances and $\mathrm{pH}_{\mathrm{w}}$ have negative loadings. The scores of $\mathrm{PC} 1_{\mathrm{GEO}}$ decrease with depth from highly positive values at the top of the sequence to negative values at $40 \mathrm{~cm}$, and then increase gradually until the bottom of the core, where scores are near zero (Table S2). Thus, $\mathrm{PC}_{\mathrm{GEO}}$ is interpreted as the SOM content and the general decomposition trend with time. The decreasing with depth sample scores result from high organic matter amounts due to recent vegetation contributions in the top of the core, and progressively lower SOM amounts at greater depths. The ${ }^{13} \mathrm{C}$ abundance, which has a strongly negative loading in $\mathrm{PC} 1_{\mathrm{GEO}}$, is in the range of the values obtained for soils developed under $\mathrm{C} 3$ vegetation as reported in the literature [65].

The $\mathrm{PC} 2_{\mathrm{GEO}}(26.8 \%$ of the variance) is related, with positive loadings, to $\mathrm{Al}, \mathrm{Pb}$, and $\mathrm{d}^{15} \mathrm{~N}$, while $\mathrm{Mn}, \mathrm{Fe}, \mathrm{CN}$, and $\mathrm{P}$ have negative loadings. The sample scores of $\mathrm{PC} 2_{\mathrm{GEO}}$ are positive and increase with depth from 0 to $70 \mathrm{~cm}$, where they drop to negative values that remain to the bottom of the core. From these results, the $\mathrm{PC} 2_{\mathrm{GEO}}$ is interpreted as the degree of humification of $\mathrm{OM}$ and its associated soil chemistry, and reflects the effect of the different degradation paths depending on the hydromorphic environment and on the intensity of soil use. The-at least periodic-reducing conditions due to hydric saturation seems to be partially responsible for the geochemical properties in the lower part of the core $(90-125 \mathrm{~cm})$, where sample scores of $\mathrm{PC} 2_{\mathrm{GEO}}$ are negative. This part of the sequence shows variable amounts of $\mathrm{Fe}$ and $\mathrm{Mn}$, reflecting redox processes, and the highest $\mathrm{C} / \mathrm{N}$ ratios of the soil. The high amounts of $\mathrm{P}$ observed in this part of the core are likely due 
to modern contributions from groundwater, since phosphate, which is highly soluble in acid environments, is frequently used as a fertility amendment in agricultural plots of the area. In turn, the upper part of the soil (from 0 to $70 \mathrm{~cm}$ ) displays a geochemical signal that points to a more humified OM. This is expressed as lower CN ratios than in the lower part of the sequence, as well as in the higher amounts of Al which, in acid soil environments is normally forming complexes with humic substances. The abundance of ${ }^{15} \mathrm{~N}$ is also high in this part of the soil, which points to an intensified soil use [66] and suggests the addition of livestock manures $[24,67,68]$.

In turn, $\mathrm{PC} 3_{\mathrm{GEO}}\left(12.7 \%\right.$ of the variance) and $\mathrm{PC} 4_{\mathrm{GEO}}(9.4 \%$ of the variance) reflect the composition of the inorganic material, and together can be considered as indicators of landscape stability. The PC $3_{\mathrm{GEO}}$ has positive loadings for $\mathrm{Y}, \mathrm{Ga}$, Th and Zr. In soils developed on granites, these elements tend to be enriched in the soil silt and clay fractions compared to the parent material $[69,70]$. Calcium, in contrast, which in acid soils is normally linked to organic compounds and/or primary minerals, has a negative loading

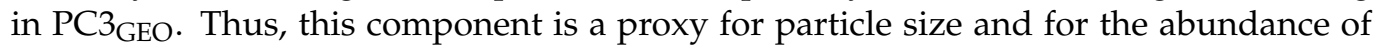
primary vs secondary minerals, i.e., for pedogenesis. The scores in PC $3_{\mathrm{GEO}}$ are highly positive in the samples at $5-30 \mathrm{~cm}$ and in samples at $70-80 \mathrm{~cm}$. It however displays an overall irregular pattern, showing periods of increased pedogenesis alternating with others in which primary materials are proportionally more abundant.

On the other hand, $\mathrm{PC} 4_{\mathrm{GEO}}$ has positive loadings for $\mathrm{Si}$ and negative for $\mathrm{Ca}$ and $\mathrm{Rb}$. It is interpreted as a proxy for the different composition of the granitic parent material in the sediment source areas, which have a variable abundance of $\mathrm{K}$ feldspars and plagioclase [71,72]. The scores in $\mathrm{PC} 4_{\mathrm{GEO}}$ increase from negative values in the soil surface to the highest positive scores in samples at 15-35 cm, and drop to negative scores, the lowest of the sequence, between 35 and $60 \mathrm{~cm}$. From $60 \mathrm{~cm}$ to downwards, the scores increase again following a saw pattern until the bottom of the core (Table S2) accounting for different source areas of the sedimentary materials in different moments.

This variability in the inorganic fraction is also reflected in the mineralogical composition of the core. The results of the X-Ray diffraction analysis are consistent with a granitic mineralogy, with quartz, K-feldspars, and plagioclase identified in all the samples with different relative abundances (data available in Table S3). The main variations in mineralogical variability are summarized by the results of the PCAXRD, which extracts two components that explain $92.8 \%$ of the variance (Table S3). The samples at $25-65 \mathrm{~cm}$, 75-90 cm, 95-115 cm, and 120-125 cm have high positive loadings in PC1 XRD, which relates to a larger content of quartz and feldspar. The diffractograms of these samples show a very low baseline, suggesting a high crystallinity, indicative of higher abundance of primary minerals. In contrast, the samples at 0-25 cm, 65-75 cm, 90-95, and 115-120 cm have high positive loadings in $\mathrm{PC} 2 \mathrm{XRD}$, thus showing comparatively higher amounts of amorphous or lowly crystalline compounds and micas and comparatively less feldspar and quartz.

Combining the results on geochemical and mineralogical composition, the hierarchical cluster analysis (CA) separated the core into three main units (see dendrogram and groups assignment in Table S4). By comparing these sample clusters with the age-depth model, three chronological periods can be defined. The bottom unit (70-125 cm, cluster 1), corresponds broadly to the period 1150-1320 AD. This unit can be further split into two subgroups: one from the bottom of the sequence at $125 \mathrm{~cm}$ to $100 \mathrm{~cm}$ of depth, with more $\mathrm{Fe}, \mathrm{Mn}$ and other trace metals and a less humified organic matter (as per the C/N ratio), and other including the samples at 95 to $70 \mathrm{~cm}$ of depth, with a comparatively higher pedogenetic development. A second unit (cluster 2, corresponding to mid-14th to late 17th century) is defined between 30 and $70 \mathrm{~cm}$, and is characterized by a lower amount of highly humified organic matter, and by a relatively high proportion of primary minerals. This second unit can be also be subdivided as two groups: from 55 to 70 and from 30 to $55 \mathrm{~cm}$, which show differences in the content of $\mathrm{Si}, \mathrm{Ca}$ and $\mathrm{Rb}$ that suggest a different sediment source area. The uppermost unit (cluster 1, representing the 20th century) includes the 
samples from 0 to $30 \mathrm{~cm}$. Within this group, the two samples at $0-5 \mathrm{~cm}$ and at $5-10 \mathrm{~cm}$ are geochemically different from the samples at $10-30 \mathrm{~cm}$, and cluster independently.

\subsection{Phases of Creation of the Santa Mariña Landscape}

The myth of Santa Mariña is assumed to have probably been introduced in the 5th century by Hydatius, a local Christian leader born in the nearby ancient Forum Limicorum [73]. Hydatius reinterpreted a pagan Iron Age sauna into the cremation oven-the Forno da Santa (the "Saint's Oven") —in which Mariña should have been burnt, and made it one of the key elements of the Santa Mariña martyrdom and a place of worship. The transformation of the Forno da Santa into a small Christian chapel in the Early Middle Ages, dated in $545 \pm 40$ through OSL [74], is interpreted as the consolidation and institutionalization of this narrative [73].

This 6th century date is consistent with the chronology of the origins of the traditional Galician landscape as revealed by previous investigations in the region, and it is better understood in the framework of the change brought about by the implantation of Christianity as a unique religious form in Western societies from Roman times. This has arguably constituted a paramount factor in landscape change at a continental scale, beginning in the city of Rome [75] and extended to other cities of the Empire [76,77] and to the countryside [78-81], following the spread of Christianity [82]. In NW Spain, this process is reflected on what has been called a "Christian geography" $[83,84]$ in which the territory has been subjected to a process symbolic appropriation of land for its conversion into a Christian landscape. This is evident in toponyms, with some mountains named after saints, and each parish recognized by a topographical feature or a landmark together with the name its patron saint [85], with a particularly high frequency in NW Spain -a map of the places in Europe with the words "Saint" or "Holy" in their names can be found in [86].

This appropriation has had a tangible dimension too, by selectively modifying or preserving pre-existent land uses, and with a direct reflection in landscape patterns and even in topography. The beginning of this process has been set, through archaeological research, in the Late Antiquity-Early Middle Ages [23,87-89]. Reasons for these transformations have probably to be traced back to climate and productive factors [23,24], including enhanced soil erosion and a lower agricultural productivity that resulted from the Cold Medieval Period climate conditions [90-92]. Furthermore, some authors hypothesize about the use of these agricultural infrastructure interventions, in particular terraces construction or refurbishment, for intentionally "attaching the rural population to the land, to facilitate the development of feudalism, and the productive apparatus which later enables the Romanesque" [93]. Indeed, the specific geographical implementation of these interventions followed the requirements of the Christian expansion in the region [94]. This early phase, however, is not reflected in SM3 record, for which its oldest date is ca. $1100 \mathrm{AD}$.

\subsubsection{2th to Early 14th Centuries}

The climate in this period is determined by the Medieval Climate Anomaly (MCA), which produced temperatures up to $3.5^{\circ} \mathrm{C}$ higher than the 1960-1990 average [95], and has its highest expression between 1100 and $1300 \mathrm{AD}$. The MCA is, in addition, characterized by an increase in precipitations and high primary productivity [96].

In the first phase of this period as reflected by SM3 pedo-sedimentary sequence (ca. 1100 to ca. $1200 \mathrm{AD})$ the sediment accumulation at Santa Mariña is very fast $\left(0.48 \mathrm{~cm} \mathrm{y}^{-1}\right.$ on average, Figure 3). The processes of sediment deposition may be diverse and depend on multiple factors (including climate, lithology, topography, vegetation cover, impacts of anthropogenic activities) and, consequently, the rates of colluvial sediment accumulation produced by different processes can vary too. We, however, interpret that these high rates of sediment accumulation are a consequence of anthropogenic modifications of topography (i.e., terracing). This interpretation is first based on the comparison with the accumulation rates reported for other colluvial sequences in Galicia having similar lithology and analogous topography, which show much slower accretion, ranging $0.025-0.07 \mathrm{~cm} \mathrm{y}^{-1}$, for a col- 
luvial soil formed by granite sediments that spans the last $11 \mathrm{ky}[97]$ and $0.03-0.05 \mathrm{~cm} \mathrm{y}^{-1}$ in a Roman Ages paleosoil developed on amphibolite colluvium [24]. In contrast, rates of sediment accumulation comparable to the values found at this phase of Santa Mariña history $\left(0.2-0.6 \mathrm{~cm} \mathrm{y}^{-1}\right)$ have been reported for terraced soils [24].

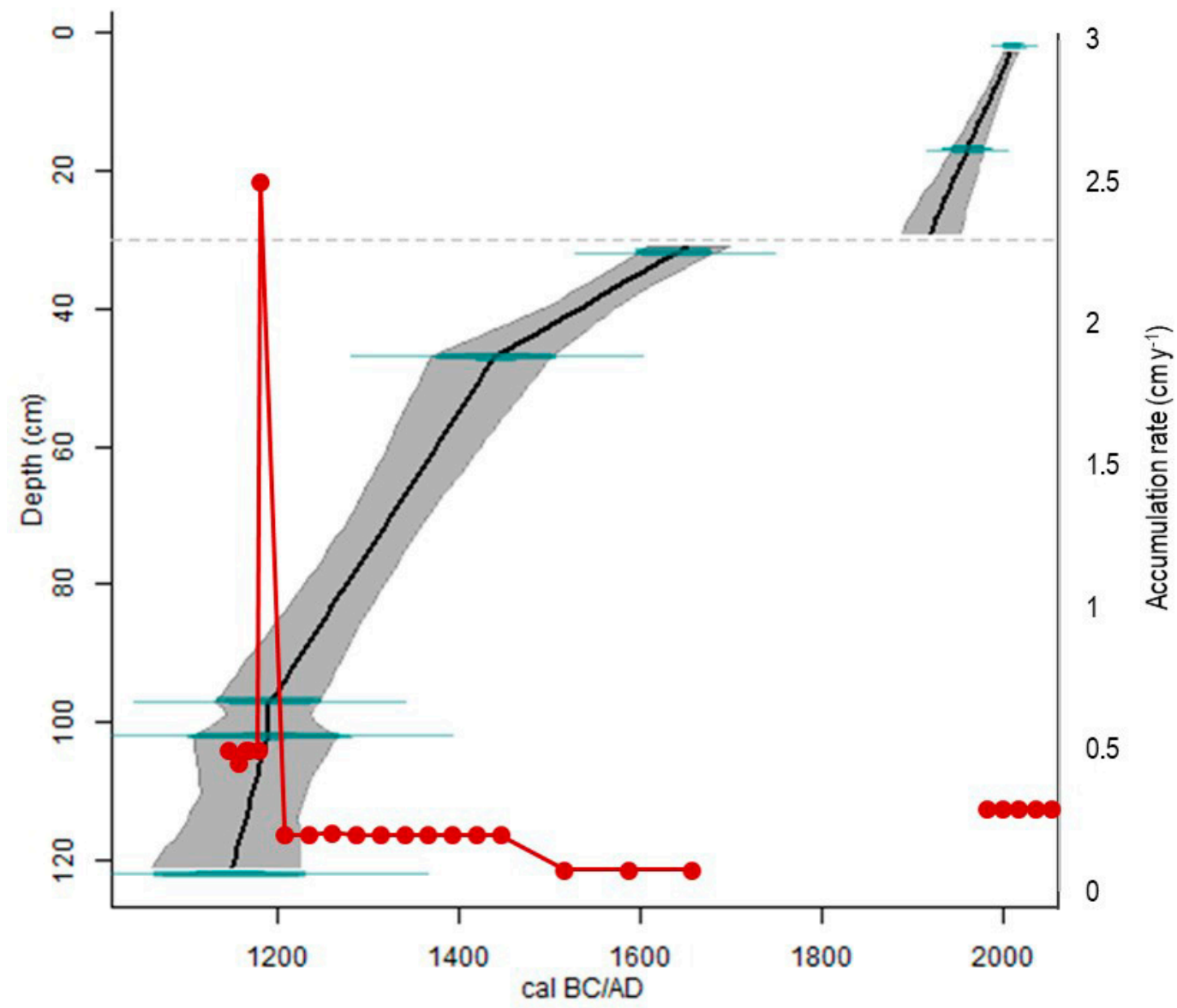

Figure 3. Age depth model obtained from the dates listed in Table 1 using Clam software (Blaauw 2010). The most probable date is depicted in black with the shaded showing the $95 \%$ probability interval for each sample. The red line indicates the calculated accumulation rates.

A second line of evidence for this interpretation is provided by the fact that the thalweg had originally, before any modification of topography, a natural slope (Figure 2). Thus, any high-energy erosion event capable to quickly mobilize large amounts of sediments from the adjacent slopes would necessarily also produce erosion in the thalweg, unless sediment flushing out is actively avoided. In fact, the bottom of the sampled sequence, dated at the beginning of 12th century, is assumed to be sitting directly on top of the granitic rock, thus demonstrating that erosion, rather than sedimentation was the dominant process in the area before that moment, and that the net accumulation of sediment started only when topography was corrected. The heterogeneous particle size of the mineral fraction of these samples provides further support to this interpretation, as it seems to discard water as sedimentation agent, as well as the irregular variation of the geochemical composition of the samples shown by $\mathrm{PC} 3_{\mathrm{GEO}}$ and $\mathrm{PC} 4_{\mathrm{GEO}}$.

The reasons for a modification of topography could have been diverse: for example, widespread deforestation together with high rainfall could have made convenient the adoption of soil conservation measures and/or strategies for protecting downstream built structures from erosion as seen in [25]. Previous research on vegetation change at a regional scale shows that deforestation at this time is generalized $[98,99]$ as a result of the territorial expansion of agricultural activities, also seen in other parts of Spain [100-103]. In the 
case of Galicia, deforestation seems to have been largely related to the newly introduced technologies of soil fertilization. These are based on the addition of shrub collected in the highlands to the intensively cultivated lowlands [24]. The amount of shrub required is, according to estimates by Balboa López [104], as high as 8-16 metric tons per hectare of cultivated land per year, which illustrates the importance of the uncultivated highlands (monte) for agricultural productivity. For ensuring a reliable supply, enough for an effective fertility amendment, the extension of monte needed is three times the extension of the farmed lands [105]. This is consistent with the strong increase in shrubs pollen (Ulex and Calluna spp.) observed for this period in the paleo vegetation record throughout the region $[98,99]$ and illustrates the large impact on environment derived from agricultural activities at this moment.

In the samples of the SM3 core corresponding to this phase, there is also a relatively high abundance of charcoal, which suggests the use of fire as a landscape management tool for simultaneously maintaining the fertility of the highland soils and regenerating the shrubland $[97,106]$, by taking advantage of the pyrophytic nature of Ulex spp. The geochemical signal of SM3 core shows in fact evidence of agricultural use in this period (positive scores in $\mathrm{PC} 2_{\mathrm{GEO}}$, Figure 4). In particular, it displays an increase of $\delta^{15} \mathrm{~N}$ in the upper part of this group of samples that suggests the use of animal manures. This is in agreement with other investigations that have dated the earliest evidence of intentional addition of animal manures as fertilizer in this region around the 11th century [24]. These would have been applied as estrume, a mixture of cattle dungs with Ulex shrubs collected in the areas of extensive management.

However, the terrace may also have been built for purposes different from agriculture. One possible option is that topography was modified in relation to a major refurbishment of the chapel, which consisted in the construction of a semi-circular barrel vault on the antechamber, around the 12-13th century [19]. This reform is best understood in the framework of an intentional refueling of the cult of Santa Mariña, including also the compilation of the miracles of her martyrdom, when the area became part of the territory of the Ourense Cathedral after mid-12th century. This renovated interest is also demonstrated by the construction in late 12th to early 13th century of the church of Santa Mariña de Augas Santas [107], of Romanesque style, which is located $650 \mathrm{~m}$ away from the Basilica, up in the hill. The surface resulting from this reform could have then been used for agricultural production, which would explain the geochemical signal of these samples.

The role of religious practice and ecclesiastical structures in shaping specific past and contemporary production systems has been acknowledged in a number of studies $[15-17,107,108]$. In Galicia, previous works have provided evidence for the construction of agricultural terraces linked to the Church activity $[23,109,110]$. The landscape reorganization during this period-including the construction and modification of agrarian terraces-and the related territorial articulation cannot be explained simply by either a centralized power (monarchy) or peasant activity, but seem to imply a level of intermediate authority [94], as seen also in other locations of the N and NW Iberian Peninsula [111]. Thus, this landscape transformation has to be read as a further phase in the process of Christianization of the territory started centuries earlier [83] under the broader framework of the development of the socioeconomic and political structures of feudalism, and that has analogues in other regions of Europe [112-115].

Importantly for the evolution of Santa Mariña, whether the terrace was constructed for agricultural or religious aims, the chronological coincidence of both facts provides evidence that religious and productive uses shared the same space, thus revealing an early multifunctional configuration of the site. 


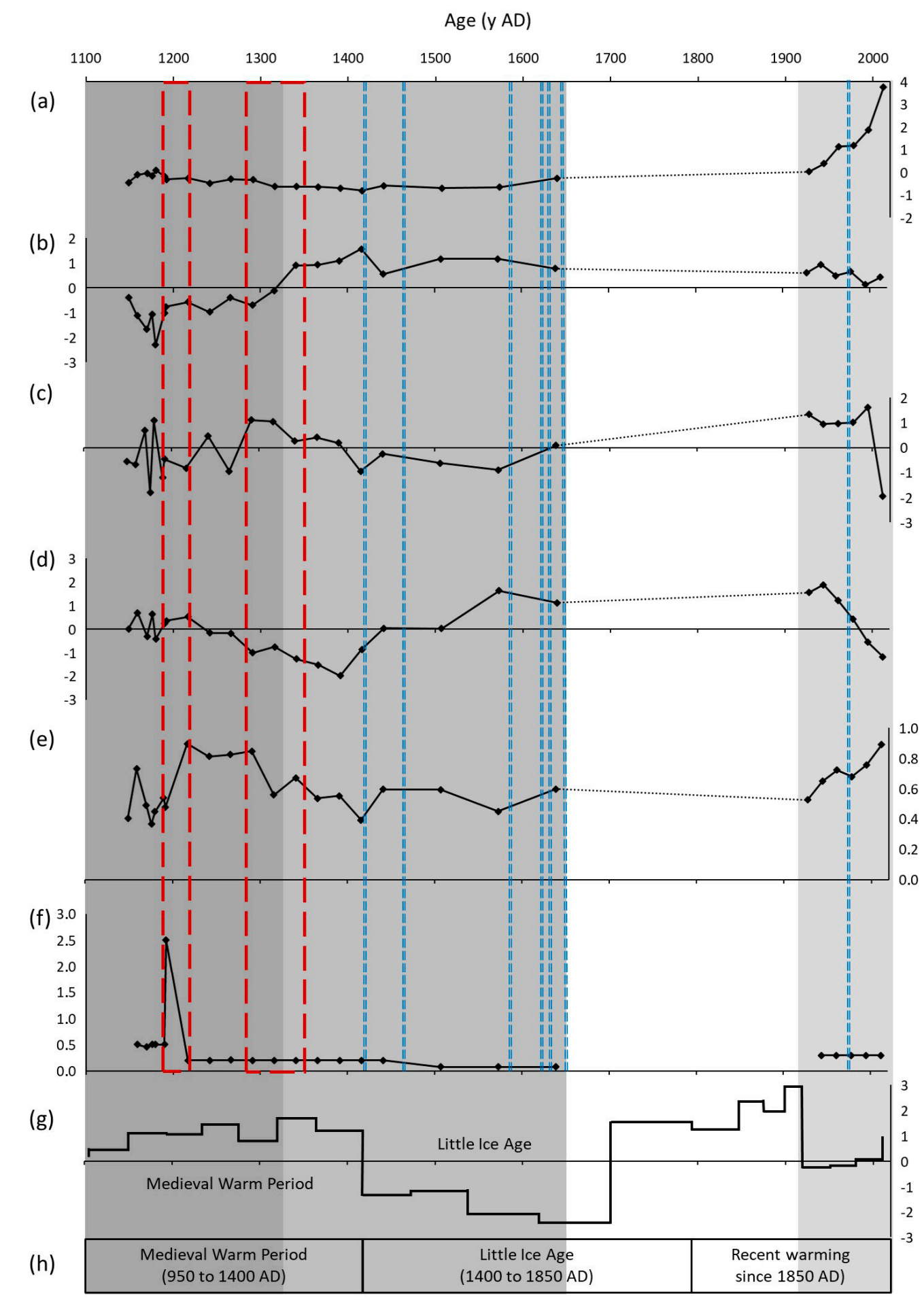

Figure 4. The factors of formation of the sedimentary record are depicted in relation to the chronological framework: (a) sample scores of $\mathrm{PC} 1_{\mathrm{GEO}}$, showing the decomposition of soil organic matter; (b) sample scores of $\mathrm{PC} 2_{\mathrm{GEO}}$, which represents intensity of land use; (c) sample scores of $\mathrm{PC} 3_{\mathrm{GEO}}$, which are a proxy for the proportion of primary vs secondary minerals; (d) sample scores of $\mathrm{PC}_{\mathrm{GEO}}$, showing the variations in sediment source; (e) sample loadings of PC2 $\mathrm{MIN}$, representing the degree of pedogenesis; (f) sediment accumulation rates. The dominant climate conditions at the regional scale are shown in (g) temperature index from Martínez-Cortizas et al., (1999); and (h) climate periods from Desprat et al., (2003). The periods when the main reforms of the religious buildings were made are shown in m-dashed red rectangles, and the punctual minor maintenance interventions are in n-dashed blue lines (dates from Blanco-Rotea et al., 2015 and Sanjurjo-Sánchez et al., in press), as described in the text. The shades of grey indicate the sample clustering as calculated by the hierarchical cluster analysis (cluster 1, 2, and 3 depicted in dark, medium, and light grey). 
The second phase of this period (1200-1340 AD) is geochemically different from the first one, showing a compositional discontinuity at $100 \mathrm{~cm}$ of depth that could be read as a change in the sedimentological regime involving an erosive event. However, the dates obtained for the sample at the top of the previous phase and the one at the bottom of the second phase are statistically equal. Thus, there is no chronological hiatus at this depth (Figure 3), and we interpret the compositional differences between the two phases as a consequence of the hydromorphic conditions that periodically affect the bottom part of the sequence (below $100 \mathrm{~cm}$ ). Consistently, the differences in composition are most noticeable for the elements susceptible to suffer redox processes, as well as in the properties that reflect the degree of decomposition of organic matter, as reflected in PC2. Additional evidence is provided by the vertical variation of the $\mathrm{BrC}$ molar ratio (Table S1). The ratio between $\mathrm{Br}$ and $\mathrm{C}$ reflects the degree of halogenation of the soil humic substances [116], a process that happens to be linked to SOM decomposition in aerobic soil environments and reflects the age of the SOM in acidic soils. Under anaerobic conditions, on the contrary, the decomposition of the organic matter is slower, thus producing $\mathrm{C}$ accumulation and dehalogenation of previously halogenated compounds is favored over halogenation [117], resulting in lower $\mathrm{BrC}$ ratios than expected for the soil age [116]. In agreement with this, the depth profile of $\mathrm{BrC}$ ratio shows lower values at the bottom of the sequence, where morphological evidence of hydromorphic conditions was found.

In addition, this second phase shows a lower expression of some of the markers of agricultural activity, compared to the previous one. In particular, $\delta^{15} \mathrm{~N}$ values are lower and fairly invariant through time. The sedimentary material corresponding to this phase has a finer and more homogeneous particle size, which also agrees with the higher proportion of non-crystalline fraction and lower of primary crystalline found by X-ray diffraction analyses.

Although lower than in the previous phase, the sediment accumulation in this period is also fast $\left(0.20 \mathrm{~cm} \mathrm{y}^{-1}\right.$, see also Figure 3). Chronologically, the deposition of this part of the core coincides with a second reform of the building, which results in its current appearance, by converting the previous chapel and Forno in a buried crypt, and constructing the much more monumental Basilica at the top of it (although the Basilica was never finished), which doubled the dimensions of the previous chapel in width and length. A singular group of more than 100 small votive earthenware jars found in the outlet canal of the primitive sauna has also been dated in this period [38]. The construction of a staircase for accessing the now underground structures indicates that the new building welcomes and aims to keep the old tradition alive. From the stratigraphic and typomorphological study of the arches and vaults and of the few decorations available [74], and the OSL dating of the mortars sampled in the walls of the Basilica [39], this reform was dated in the 13th-14th centuries. This chronology coincides with the estimates of other authors from the study of documentary and historical sources $[107,118]$, that report a renovated momentum in the cult of Santa Mariña.

While we acknowledge that coincidence and correlation do not imply causal relationships, we interpret from the combination of all these data that a topographical transformation of the land surrounding the Basilica was carried out simultaneously and/or linked to the building reform. The fast accumulation of sediment in this phase would thus be anthropogenic, and would provide further evidence of the landscape transformation capacity of religious phenomena. It is however necessary to stress at this point that, albeit the core has a good resolution for this phase, the accuracy of the chronological model may be not optimal due to the lack of dates for in between samples for this phase. The dates provided have thus to be taken as estimates. In order to produce a refined conclusion in this regard, it is necessary to complement the chronological model and calculate the sediment accumulation rate with higher accuracy. 


\subsubsection{Mid-14th to Mid-17th Centuries AD}

The average rate of sediment accumulation in this period is $0.13 \mathrm{~cm} \mathrm{y}^{-1}$, although it is not homogeneous throughout the timespan. In the first phase of this period, corresponding broadly to the 14th century, the sediment accumulation rate is comparable to the rates of the previous period $\left(0.20 \mathrm{~cm} \mathrm{y}^{-1}\right)$. In contrast, the geochemical signal indicates a higher pedogenesis degree than in the previous phases (with high PC2, Figure 4), a trend that will continue in subsequent periods. These samples show lower organic matter contents (lower PC1 scores), and more humified (higher PC2 scores), with higher Al contents and $\delta^{15} \mathrm{~N}$ values that increase over time, all of which are signs of an intensification of agricultural activity. The sediment layer corresponding to this phase has, however, just $15 \mathrm{~cm}$ thickness, which suggests a minor topographic intervention, for slope correction or for flattening the surface.

From the 15th century until the first half of the 17th century, i.e., in the second phase of this period, the sediment accumulation rate drops considerably to $0.08 \mathrm{~cm} \mathrm{y}^{-1}$, value comparable to the sedimentation rates found in other areas of Galicia subjected to natural colluvial processes. The age-depth model is, in this part of the core anchored by the sample at 30-35 cm depth which shows a complete bleaching of the pre-depositional OSL signal. This suggests that the sediments were probably subjected to laminar-flow transport, which typically happens in low-grade slopes [119]. We thus interpret this layer as the result of colluviation in an already terraced topography.

The sediment input to the site could have been enhanced by the climate deterioration corresponding to the end of the Medieval Climate Anomaly and the onset of the Little Ice Age (LIA, Figure 4) from $1400 \mathrm{AD}$ [90]. The LIA brought low temperatures -1 to $2{ }^{\circ} \mathrm{C}$ lower than the average for the period 1960-1990 [95] at a hemispheric scale, accompanied by a larger climate variability [120] — which undermined agricultural production and produced "a long-term, continent-wide agricultural crisis" [121]. Although the geochemical signals of agricultural activity—also attested by documentary sources [118]—and pedogenesis remain during this period, their intensity is certainly lower than in the previous phase. The proxies for fertilization, in particular the $\delta^{15} \mathrm{~N}$ ratio, show a progressive decline in this period, which could indicate a change in agricultural management, from the use of ${ }^{15} \mathrm{~N}$ rich fertilizers in the previous period-such as the traditional estrume - towards other kinds of soil fertility management which could include, for example, crop rotations or fallow, therefore a less intensive soil use.

Several small refurbishments of the religious buildings had place during this period [19,39], providing evidence of a continued use and maintenance of the buildings, which coincides with the interest that the Santa Mariña tradition seems to draw during these centuries [122], and attest that the cult to Santa Mariña continues at the same time and in the same space than the agrarian activity.

\subsubsection{Sedimentological Hiatus Corresponding from Mid-17th to 19th Century}

The climate at the beginning of this period is marked by the cold conditions of the Maunder Minimum (1645-1715 cal AD) [90]. Historical documents reveal that a critical period occurred in this region between 1680 and 1700, when severe cold and prolonged droughts caused serious famines in farming communities [123,124]. This is supported also by the information stored in marine and peat records from northwest Iberia, which also indicate that that the coldest climate conditions of the LIA occurred around 1700 [90,95]. At a regional scale, the palynological records show a recovery of forest land, mainly as Pinus spp. plantations, during 18th and 19th centuries, mirrored by a decrease in shrubland, which supports a reduction in the extension of territory occupied by agricultural activity. The documentary sources nonetheless show that farming activities would have continued in the area through this period until the first half of 20th century.

The sedimentological data at Santa Mariña indicate that this unstable climate was indeed translated into slope soil instability, reflected as a hiatus in the depositional sequence (Figure 3). No evidence of repairs to religious buildings has been detected corresponding to 
these centuries, which could be regarded as a lower interest in the cult of Mariña. According to some authors, a generalized process occurred in all rural Galicia from the 17th century onwards [125], involving the replacement of the popular ritual aspects directly inherited from the "primitive" Christianity of the Galician communities by a more canonical ritualism. In this way, many chapels would have fallen into neglect [126], while popular faith would have been channeled through the parish churches. However, there is no evidence of such process at Santa Mariña, where, according to the available written testimonies, the cult enjoyed official status already at that moment, and it is known that the processions between the parish and the Basilica to honor the Saint had continuity during 18th and 19th centuries and until today. Proof of this are the oral testimonies of that ceremonies in the first half of the 20th century (see http:/ / santamarinadeaugassantas.com/, accessed on 1 August 2021).

\subsubsection{0th Century}

In this phase, the sediment accumulation rate returns to high values $\left(0.29 \mathrm{~cm} \mathrm{y}^{-1}\right.$, Figure 3), with the slope of the age-depth model in this part of the core conditioned by the date obtained for the sample at $17.5 \mathrm{~cm}$ of depth. The OSL measurements for this sample show a skewed distribution and a high overdispersion value (62 $\pm 13 \%$, Table 1$)$. High overdispersion values are many times attributed to partial bleaching, and may introduce a risk of flawed age estimations that happen commonly in very young samples [127]. At Santa Marina, these could be related with a very fast sediment accumulation that produces an insufficient exposure to daylight. This possibility is consistent with a major transformation of the site documented in 1962, which consisted in the construction of a concrete drainage trench surrounding the Basilica, in order to prevent its deterioration due to the seasonal water flooding of the crypt. This modification involved the removal of a considerable amount of earth from previously deposited sediment layers surrounding the basilica and its deposition in the soil surface, and could produce an overestimation of the age of deposition of the sediments of this part of the sequence.

On the other hand, partial bleaching may also be related to the mixing of the sedimentary material of the upper soil part due to tillage, and would likely result in an age younger than the real date of deposition of the material. This second possibility is supported by the young date obtained for this sample and by the geochemical properties of this soil layer-with high organic contents and decreasing $\delta^{13} \mathrm{C}$ values towards the soil surface, and increased P contents (see Table S1). The $\delta^{15} \mathrm{~N}$ values, however, continue the decreasing trend towards surface that started in the previous phase, pointing to a less intensive soil use [66]. While it is known through written and graphic sources that the broader area was under cultivation during the 20th century (see Figure 5), the exact plot where the Basilica and the SM3 core are located has not been farmed in the last decades, and it is currently kept as a grassland. 


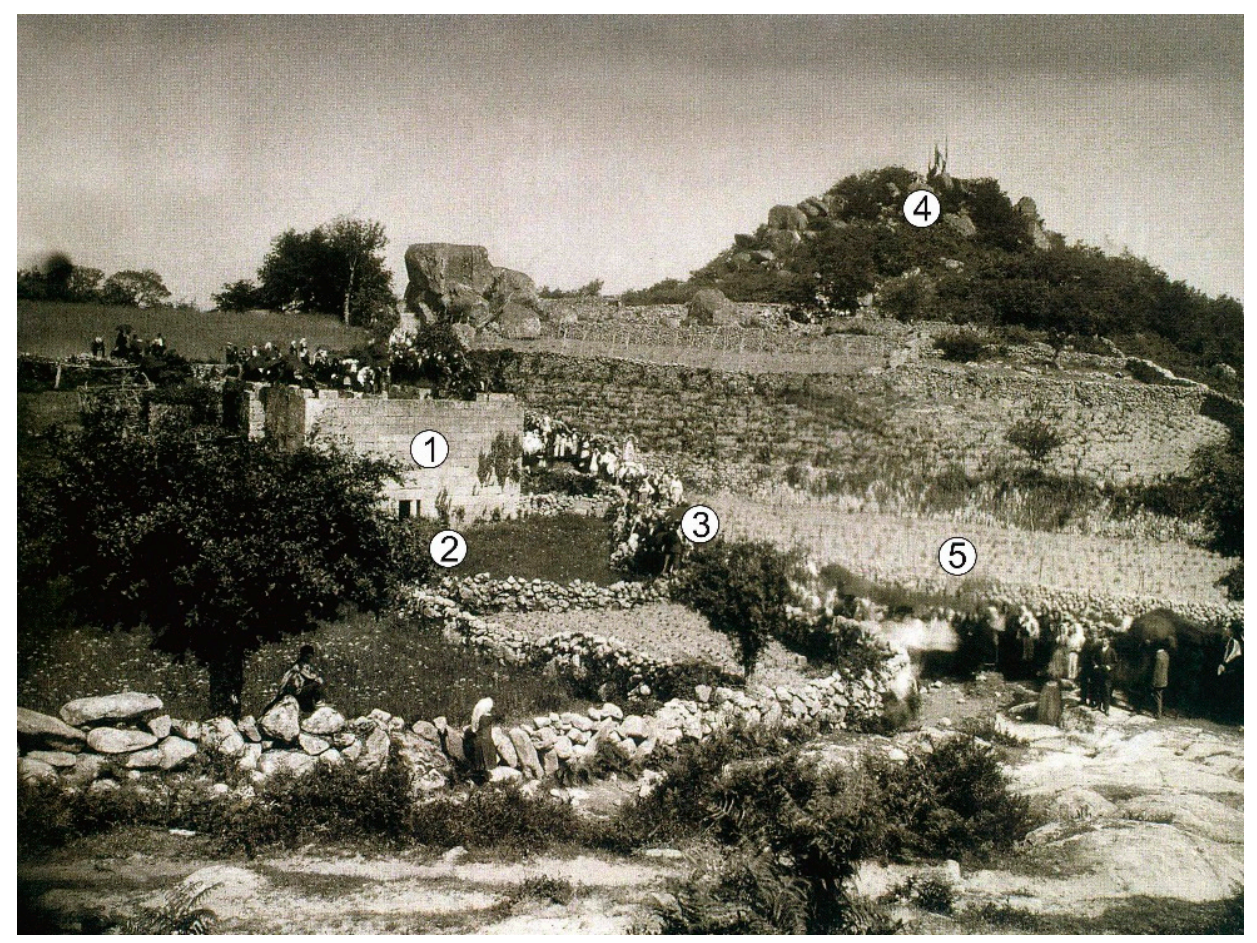

Figure 5. Anonymous photograph of the Basilica and its surroundings during the celebration of Santa Mariña day (18th of July) in the 1930s. The area was under agricultural use, although some of the plots, including the one in which the Basilica is located are grasslands. The numbers show the different landmarks mentioned in the text: (1) the Basilica, unfinished since 13th-14th centuries, when the currently visible structure was built, and under which is the Forno da Santa; (2) plot in which the SM3 core was collected; (3). Path that communicates the parish church with the Outeiro dos Pendóns (4) which is the highest topographical elevation of the nearby Iron Age hillfort Castro de Armeá; and (5) non-terraced farmed agricultural plots.

The coexistence of the production and religious uses is in any case demonstrated, both by the oral testimonies (see http:/ / santamarinadeaugassantas.com/, accessed on 1 August 2021) and by the interest in preserving the integrity of the buildings, at the same time than the land was used for grazing or cultivation.

\subsection{On the Multifunctionality of Santa Mariña Landscape}

The joint evidence of agricultural use and modification of religious buildings demonstrates that the worship and the agricultural activities have shared physical and social space since as early as the Middle Ages (Table 2). Thus, in line with Ingold's view of landscapes as a "work in progress" [128], Santa Mariña has evolved combined multiple uses, notably religious and agricultural, during more than a millennium, to produce the landscape features we can see today. The multifunctional character of Santa Mariña today must be understood as an evolutionary feature of the site, with its origin dating back to the Middle Ages. In other words, the Santa Mariña landscape is not just multifunctional, but rather multifunctionality has created Santa Mariña landscape. 


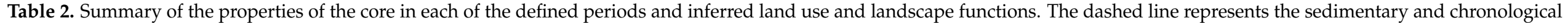
hiatus.

\begin{tabular}{|c|c|c|c|c|}
\hline $\begin{array}{l}\text { Modelled Age } \\
\text { (cal AD) }\end{array}$ & Period & $\begin{array}{c}\text { Geochemical and Sedimentological } \\
\text { Properties }\end{array}$ & Local Context & $\begin{array}{l}\text { Inferred Land Use (Landscape } \\
\text { Function) }\end{array}$ \\
\hline $\begin{array}{l}2012 \\
1995 \\
1978 \\
1961 \\
1944 \\
1927\end{array}$ & 20th century & $\begin{array}{l}\text { High sediment accumulation rate. } \\
\text { High } C \text { and } P \text { contents. Decrease in } \delta^{15} \mathrm{~N} \text {. }\end{array}$ & $\begin{array}{c}\text { Major transformation of the Basilica in } 1962 . \\
\text { Grassland in the last decades. }\end{array}$ & $\begin{array}{l}\text { Religious and less intensive } \\
\text { agriculture (cultural, provision). }\end{array}$ \\
\hline $\begin{array}{l}1639 \\
1573 \\
1507 \\
1441 \\
1416\end{array}$ & $\begin{array}{l}\text { Late Medieval and Modern } \\
\text { Periods }\end{array}$ & $\begin{array}{l}\text { Low accumulation rates: colluvial processes. } \\
\text { Decrease in } \delta^{15} \mathrm{~N} \text {. }\end{array}$ & Several minor refurbishments of the Basilica. & $\begin{array}{l}\text { Religious and less intensive } \\
\text { agriculture (cultural, provision). }\end{array}$ \\
\hline $\begin{array}{l}1391 \\
1366 \\
1341\end{array}$ & & $\begin{array}{l}\text { High accumulation rate. Higher degree of } \\
\text { pedogenesis. Increased } \mathrm{Al} \text { content and } \delta^{15} \mathrm{~N} \text {. }\end{array}$ & & $\begin{array}{l}\text { Religious and intensive agriculture } \\
\text { (cultural, provision). }\end{array}$ \\
\hline $\begin{array}{l}1316 \\
1291 \\
1266 \\
1242 \\
1217 \\
1192\end{array}$ & High Middle & $\begin{array}{c}\text { High accumulation rate. } \\
\text { Lower } \delta^{15} \mathrm{~N} \text { and finer and more } \\
\text { homogeneous particle size of sediments in } \\
\text { this phase. }\end{array}$ & $\begin{array}{l}\text { Second reform of the building: burial of the } \\
\text { chapel and construction of the Basilica. }\end{array}$ & $\begin{array}{l}\text { Religious and less intensive } \\
\text { agriculture (cultural, provision). }\end{array}$ \\
\hline $\begin{array}{l}1190 \\
1180 \\
1176 \\
1170 \\
1159 \\
1149\end{array}$ & Ages & $\begin{array}{l}\text { Very high sediment accumulation rate: } \\
\text { terracing. } \\
\text { Hydromorphic properties. Abundance of } \\
\text { charcoal, increase in } \delta^{15} \mathrm{~N} \text {. }\end{array}$ & $\begin{array}{l}\text { Large reform of the Santa Mariña chapel and } \\
\text { construction of the parish church. }\end{array}$ & $\begin{array}{l}\text { Religious and agriculture (cultural, } \\
\text { provision). }\end{array}$ \\
\hline
\end{tabular}


This is arguably not exclusive of Santa Mariña; these interactions have likely happened at other traditional agriculture sites in Galicia and worldwide. Medieval transformations of topography linked to ecclesiastical rule have been reported also in other areas of the $\mathrm{N}$ of the Iberian Peninsula [100-103]. While not been discussed from the prism of multifunctionality, these works reported data that point to a prolonged interrelation of cultural and provision aspects. For example, [101] (p. 66) report on the reorganization of the Zornoztegi village, located in the North of Spain, during the 10th-11th centuries "around the new church of Santa Maria, freeing a large space where terraces were then constructed", or at Zaballa, where "the domestic household was moved to the valley bottom" when a monastery was built, and "[agricultural] terraces were built along the valley slopes". These works do not discuss the interplay of multiple landscape functions nor if these landscapes have been multifunctional from their inception, but they nonetheless attest that religion has been an important factor of landscape configuration in different geographic areas since early Middle Ages. In other cases as in [100] (p. 42), the multifunctional character of the early medieval rural landscape is explicitly mentioned. However, only the productive dimension is discussed, thus interpreting multifunctionality as a diversity of agrarian practices that could have occupied the same space in different moments of the year, or coexisted as complementary activities (farming, forestry).

The work presented here has demonstrated that apparently distant techniques and disciplines, such as archaeometric research, agronomic characterization of soils, documentary study of the symbolic Christianization, archaeology of buildings, and investigation of the formation of the sedimentary record, can and must be combined when studying the construction and evolution of multifunctional landscapes. The extreme complexity of landscape evolution processes makes information from all disciplines and from all perspectives (different epistemologies and diverse scales) necessary for landscape studies. In this regard, we are aware that our work could be upgraded by the contributions of, for example, the political ecology perspective, and of sociological and ethnographical research, as well as from the information provided by landscape connectivity and ecosystem services studies, among others. We also acknowledge that the specific changes identified at Santa Mariña cannot be directly extrapolated to wider geographical extensions, given the small dimensions of the site and its historical particularities.

Nonetheless, this work has been effective in identifying long-term multifunctionality, as well as in providing data on the interaction between cultural and provision in order to produce current landscape configuration. These are processes not only possible but likely in other locations, and they should be taken into consideration when studying past and present landscape multifunctionality elsewhere. It has also highlighted that a long term, evolutionary perspective is of interest when addressing the study of present land use sustainability, in order to fully understand the why's and the how's of current landscape configuration, in line with recent studies [22,129]. However, this longue durée view is often disregarded in modern sustainability debates. We advocate for an interdisciplinary problem-oriented design of research which actively seeks to incorporate the information on the past provided by history, archaeology, and paleoenvironment, thus increasing the chances of success of land planning for sustainability and of developmental interventions.

\section{Conclusions}

The study of the geoarchaeological record, combined with historical, archaeological archaeometric, and documentary sources, has allowed the recognition of landscape multifunctionality at Santa Mariña de Augas Santas during the last millennium. The studied core showed good resolution for the High and Late Middle Ages, but only low resolution for the Modern era. In spite of these caveats, the proxies used allowed us to obtain a good perspective of the natural and anthropic processes that shaped the characteristics of the current landscape.

This work has shown that religious activity has been, along with agricultural exploitation, the main modifier of the landscape through the use of environmental resources, the 
transformation of land cover and land use (from forest to shrubland and agricultural land and then back to forest and/or shrubland) and the direct modification of topography. This proves that the symbolic value of land has been, in addition to productive aspects, one of the main drivers of multifunctional landscapes evolution. Thus, multifunctionality is not a recent acquisition, or the result from a specific evolution path, but an essential and idiosyncratic aspect of traditional land use strategies at Santa Mariña from their very inception. The history and long-term processes of productive systems must be taken into account when assessing the sustainability of traditional productive systems, and when planning land use strategies and developmental interventions in rural settings.

Supplementary Materials: The following are available online at https: / www.mdpi.com/article / 10.3390/land10090992/s1, Figure S1: OSL graphs, Table S1: Geochemical data, Table S2: Results of PCA $_{\mathrm{GEO}}$, Table S3: Results of PCAXRD, Table S4: Results of CA.

Author Contributions: Conceptualization, C.F.-V., R.B.-R., S.G.-R., J.S.-S. and M.V.G.Q.; methodology, C.F.-V., R.B.-R., S.G.-R. and J.S.-S.; data curation, C.F.-V. and J.S.-S.; writing-original draft preparation, C.F.-V.; writing-review and editing, C.F.-V., R.B.-R., S.G.-R., J.S.-S. and M.V.G.Q.; funding acquisition, M.V.G.Q., J.S.-S. and R.B.-R. All authors have read and agreed to the published version of the manuscript.

Funding: Partial funding was provided by the following sources: "Levantamiento volumétrico y lectura de alzados del conjunto formado por la Basílica da Ascensión y O Forno da Santa (Allariz, Ourense)" (CD 102A 2007/646-0); "Arqueoloxía e Relixión: da Idade do Ferro á Idade Media" (INCITE 2010-Xunta de Galicia, Ref. 10PXI210112PR); "Programa de investigación en tecnologías para la valoración y conservación del patrimonio cultural - Programa Consolider-Ingenio 2010" (Ref. CSD2007-00058); “Consolidación y estructuración de unidades de investigación competitivas: Grupos de potencial de crecimiento" (ED431B 2018/47 and ED431B 2021/17); Redes de investigación (R2017/008); and GI-1919 Synkrisis, Research in Cultural Forms, Santiago de Compostela University.

Institutional Review Board Statement: Not applicable.

Informed Consent Statement: Not applicable.

Data Availability Statement: The data that supports the findings of this study are available in the Supplementary Material of this article.

Acknowledgments: This study is framed into a wider research project spanning different aspects of the Santa Mariña history that started in 2008, and was carried out by a multidisciplinary team of researchers from different institutions. The massive cuts in research funding witnessed in Spain in the first years of the project involved, for many of the team members, the need to seek the continuity of their professional careers by courses often not compatible with an exclusive dedication to the project and sometimes to research. In this context, the investigation in Santa Mariña has been completed thanks to the efforts of a disperse team, largely under precarious working conditions and without specific funding for addressing it during a large part of the project. The authors of this manuscript wish to acknowledge the contribution to this research of: Patricia Mañana Borrazás from DIMENSO; Anxo Rodríguez Paz and César González-García from Incipit-CSIC; Pilar Prieto Martínez, Francisco Alonso Toucido, Rebeca Tallón Armada, José Carlos Sánchez-Pardo and Rocío Sánchez Ameijeiras, from the University of Santiago de Compostela; Alberto Rodríguez Costas, and Cristina Mato Fresán. José Carlos Sánchez-Pardo and Rocío Sánchez Ameijeiras are especially thanked for having been available for answering our queries during the preparation of this manuscript. João Fonte from the University of Exeter and, particularly, Patricia Mañana Borrazás are indebted for their support in the elaboration of the DEM and the topography graphics.).

Conflicts of Interest: The authors declare no conflict of interest. The funders had no role in the design of the study; in the collection, analyses, or interpretation of data; in the writing of the manuscript, or in the decision to publish the results.

\section{References}

1. Niemann, E. Polyfunctional landscape evaluation-Aims and methods. Landsc. Urban Plan. 1986, 13, 135-151. [CrossRef]

2. De Groot, R.S. Environmental functions as a unifying concept for ecology and economics. Environmentalist 1987, 7, 105-109. [CrossRef] 
3. Howard, P.; Puri, R.; Smith, L.; Altierri, M. A Scientific Conceptual Framework and Strategic Principles for the Globally Important Agricultural Heritage Systems Programme from a Social-Ecological Systems Perspective; Food and Agriculture Organization of the United Nations: Rome, Italy, 2008.

4. Bolliger, J.; Bättig, M.; Gallati, J.; Kläy, A.; Stauffacher, M.; Kienast, F. Landscape multifunctionality: A powerful concept to identify effects of environmental change. Reg. Environ. Chang. 2011, 11, 203-206. [CrossRef]

5. Fischer, J.; Meacham, M.; Queiroz, C. A plea for multifunctional landscapes. Front. Ecol. Environ. 2017, 15, 59. [CrossRef]

6. Loos, J.; Abson, D.J.; Dorresteijn, I. Sustainable Landscapes in Central Romania: A Social-Ecological Study on the Future of Southern Transylvania; Pensoft: Sofia, Bulgaria, 2016.

7. Vejre, H.; Abildtrup, J.; Andersen, E.; Andersen, P.S.; Brandt, J.; Busck, A.; Dalgaard, T.; Hasler, B.; Huusom, H.; Kristensen, L.S.; et al. Multifunctional agriculture and multifunctional landscapes-Land use as an interface. In Multifunctional Land Use; Mander, Ü., Wiggering, H., Helming, K., Eds.; Springer: Berlin/Heidelberg, Germany, 2007; pp. 93-104.

8. Müller, F. State-of-the-art in ecosystem theory. Ecol. Model. 1997, 100, 135-161. [CrossRef]

9. De Groot, R.; Hein, L. Concept and valuation of landscape functions at different scales. In Multifunctional Land Use; Mander, Ü., Wiggering, H., Helming, K., Eds.; Springer: Berlin/Heidelberg, Germany, 2007; pp. 15-36.

10. Bolliger, J.; Kienast, F. Landscape functions in a changing environment. Landsc. Online 2010, 21, 1-5. [CrossRef]

11. Kienast, F.; Bolliger, J.; Potschin, M.; De Groot, R.S.; Verburg, P.H.; Heller, I.; Haines-Young, R. Assessing landscape functions with broad-scale environmental data: Insights gained from a prototype development for Europe. Environ. Manag. 2009, 44, 1099-1120. [CrossRef] [PubMed]

12. Brunstad, R.J.; Gaasland, I.; Vårdal, E. Multifunctionality of agriculture: An inquiry into the complementarity between landscape preservation and food security. Eur. Rev. Agric. Econ. 2005, 32, 469-488. [CrossRef]

13. Frei, B.; Queiroz, C.; Chaplin-Kramer, B.; Andersson, E.; Renard, D.; Rhemtulla, J.M.; Bennett, E.M. A brighter future: Complementary goals of diversity and multifunctionality to build resilient agricultural landscapes. Glob. Food Secur. 2020, $26,100407$. [CrossRef]

14. Van Huylenbroeck, G.; Vandermeulen, V.; Mettepenningen, E.; Verspecht, A. Multifunctionality of agriculture: A review of definitions, evidence and instruments. Living Rev. Landsc. Res. 2007, 1, 1-43. [CrossRef]

15. Falvey, J.L. Religion and Agriculture: Sustainability in Christianity and Buddhism; Institute for International Development: Adelaide, Australia, 2005.

16. LeVasseur, T.; Parajuli, P.; Wirzba, N. (Eds.) Religion and Sustainable Agriculture: World Spiritual Traditions and Food Ethics; University Press of Kentucky: Lexington, KY, USA, 2016.

17. Rakodi, C. (Ed.) Religion, Religious Organisations and Development: Scrutinising Religious Perceptions and Organisations; Routledge: Oxfordshire, UK, 2016.

18. García Quintela, M.V. Marina concubina, Marina virgen, Boand adúltera: Fecundidad extra-marital y creación de paisajes. In Folclore y Leyendas en la Península Ibérica. En Torno a la Obra de François Delpech; Tausiet, M., Tropé, H., Eds.; CSIC: Madrid, Spain, 2014; pp. 57-80.

19. Blanco-Rotea, R.; Mañana-Borrazás, P.; Mato-Fresán, C.; Rodríguez-Costas, A. La basílica de la Ascensión y Os Fornos (Allariz, Ourense). Rev. Aquae Flaviae 2009, 41, 467-478.

20. Millennium Ecosystem Assessment. Ecosystems and Human Well-Being: Opportunities and Challenges for Business and Industry; World Resources Institute: Washington, DC, USA, 2005.

21. Iverson, L.; Echeverria, C.; Nahuelhual, L.; Luque, S. Ecosystem services in changing landscapes: An introduction. Landsc. Ecol. 2014, 29, 181-186. [CrossRef]

22. Bürgi, M.; Silbernagel, J.; Wu, J.; Kienast, F. Linking ecosystem services with landscape history. Landsc. Ecol. 2015, 30, 11-20. [CrossRef]

23. Ferro-Vázquez, C.; Martínez-Cortizas, A.; Nóvoa-Muñoz, J.C.; Ballesteros-Arias, P.; Criado-Boado, F. 1500 years of soil use reconstructed from the chemical properties of a terraced soil sequence. Quat. Int. 2014, 346, 28-40. [CrossRef]

24. Ferro-Vázquez, C.; González Prieto, S.J.; Martínez-Cortizas, A.; Criado-Boado, F. Deciphering the evolution of agrarian technologies during the last 1600 years using the isotopic fingerprint $(\delta 13 \mathrm{C}, \delta 15 \mathrm{~N})$ of a polycyclic terraced soil. Estud. Quat./Quat. Stud. 2015, 12, 39-53. [CrossRef]

25. Ferro-Vázquez, C.; Lang, C.; Kaal, J.; Stump, D. When is a terrace not a terrace? The importance of understanding landscape evolution in studies of terraced agriculture. J. Environ. Manag. 2017, 202, 500-513. [CrossRef]

26. Narbarte-Hernández, J.; Iriarte, E.; Rad, C.; Carrancho-Alonso, A.; González-Sampériz, P.; Peña-Chocarro, L.; Quirós-Castillo, J.A. On the Origin of Rural Landscapes: Looking for Physico-Chemical Fingerprints of Historical Agricultural Practice in the Atlantic Basque Country (N Spain). Sci. Total Environ. 2019, 681, 66-81. [CrossRef] [PubMed]

27. Leopold, M.; Völkel, J. Colluvium: Definition, differentiation, and possible suitability for reconstructing Holocene climate data. Quat. Int. 2007, 162, 133-140. [CrossRef]

28. García Quintela, M.V.; Seoane-Veiga, Y. La Larga Vida de dos rocas ourensanas. Arch. Español Arqueol. 2011, 84, $241-264$.

29. Morales, A. La Coronica General de España; Casa de Juan Iñiguez de Lequeríca: Alcalá de Henares, Spain, 1574.

30. Lorenzo Fernández, J. El monumento protohistórico de Augas Santas y los ritos funerarios en los Castros. Cuad. Estud. Gallegos 1948, 3, 157-211.

31. Chamoso Lamas, M. Santa Marina de Augas Santas. Cuad. Estud. Gallegos 1955, X, 41-88. 
32. Conde-Valvís Fernandez, F. Las termas romanas de la "Cibdá" de Armeá en Santa María de Augas Santas. In Actas del III Congreso Nacional de Arqueología (Galicia 1953); Institución Fernando el Católico, CSIC: Zaragoza, Spain, 1955; pp. 436-466.

33. Conde-Valvís Fernandez, F. Dos villas romanas de la Cibdá de Armea, en Santa Mariña de Augas Santas. Rev. Guimarâes 1959, 69, 472-500.

34. Bande Rodríguez, E.; Armada Bande, O. Evolución do Conxunto Histórico-artístico de Santa Mariña de Augas Santas; Diputación Provincial de Ourense: Ourense, Spain, 2002.

35. Fariña Busto, F. Santa Mariña de Augas Santas. In Guías do Patrimonio Cultural; Santiago de Compostela, Fundación Caixa Galicia: Santiago, Spain, 2002; Volume 7.

36. Barandela Rivero, I.; Lorenzo Rodríguez, J.M. El culto a Santa Mariña en el norte de la Península Ibérica y sus conexiones con la Europa Atlántica. Porta Aira 2011, 13, 117-143.

37. García Quintela, M.V. Paisajes duales en la Galicia tradicional: Estructura, génesis y transformación. Rev. Dialectol. Y Tradic. Pop. 2014, LXIX, 29-52. [CrossRef]

38. Prieto-Martínez, M.P.; Alonso Toucido, F.; Lantes Suárez, O.; Rodíguez Paz, A.; Blanco-Rotea, R.; García-Quintela, M. El depósito ritual de jarritas de la Basílica de Augas Santas (Allariz, Ourense): Un ejemplo de sincretismo religioso en la Edad Media. Archeol. Mediev. 2019, XLVI, 287-313.

39. Sanjurjo- Sánchez, J.; Blanco-Rotea, R.; García Quintela, M.V.; Burbidge, C.I. OSL dating of earthen mortars from a medieval building in North-Western Spain: Crypt of Basílica da Ascensión (Allariz, Ourense). Radiocarbon 2020, 62, 679-692. [CrossRef]

40. Fernández Fernández, A.; Lago Cerviño, M.; Grande Rodríguez, M.; Pérez Losada, F.; Vázquez Mato, M.X. Monte do Señoriño (Armea-Allariz): Un nuevo asentamiento de inicios de la romanización en el Noroeste Peninsular. In CIAC XVIII Congreso Internacional de Arqueología Clásica; Álvarez Martínez, J.M., Nogales Basarrate, T., Rodà de Llanza, I., Eds.; Museo Nacional de Arte Romano: Mérida, Mexico, 2014; Volume 2, pp. 1769-1772.

41. Fernández Fernández, A.; Valle Abad, P.; Casal, L.; Fernández, L. La cerámica galaico-romana deArmea (Allariz). Monte do Señoriño y Castro de Armea. In Monografías Ex Offcina Hispana II. As Producçoes Cerámicas Deimitaçao na Hispania; Morais, A., Fernández, A., Sousa, M.J., Eds.; Oporto: St Leonards, Australia, 2014; Volume I, pp. 281-301.

42. Fernández Fernández, A.; Rodríguez Nóvoa, A.A. Contextos cerámicos de época romana de la "cibdá" de Armea (Santa Mariña de Augas Santas, Allariz). Un ejemplo de consumo y abastecimiento de una ciudad galaico-romana del interior de la Gallaecia. In Amphorae ex Hispania: Paisajes de Producción y Consumo: III Congreso Internacional de la Sociedad de Estudios de la Cerámica Antigua (SECAH)_Ex Offcina Hispana; Járregay, R., Berni, P., Eds.; Instituto Catalán de Arqueología Clásica: Tarragona, Spain, 2016; pp. 861-873.

43. Guitián, F.; Carballas, T. Técnicas de Análisis de Suelos; Ed. Pico Sacro: Santiago de Compostela, Spain, 1976.

44. Urrutia, M.; García-Rodeja, E.; Macías, F. Determinación del pH en suelos de carga variable de Galicia. Analales Edafol. Agrobiol. $1989,48,219-228$.

45. Viveen, V.; Sanjurjo-Sanchez, J.; Goy-Diz, A.; Veldkamp, A.; Schoorl, J.M. Paleofloods and ancient fishing weirs in NW Iberian rivers. Quat. Res. 2014, 84, 56-65. [CrossRef]

46. Heer, A.J.; Adamiec, G.; Moska, P. How many grains are there on a single aliquot? Anc. TL 2012, 30, 9-16.

47. Murray, A.S.; Wintle, A.G. Luminescence dating of quartz using an improved single-aliquot regenerative-dose protocol. Radiat. Meas. 2000, 32, 57-73. [CrossRef]

48. Murray, A.S.; Wintle, A.G. The single aliquot regenerative dose protocol: Potential for improvements in reliability. Radiat. Meas. 2003, 37, 377-381. [CrossRef]

49. Truelsen, J.L.; Wallinga, J. Zeroing of the OSL signal as a function of grain size: Investigating bleaching and thermal transfer for a young fluvial sample. Geochronometria 2003, 22, 1-8.

50. Galbraith, R.F.; Roberts, R.G. Statistical aspects of equivalent dose and error calculation and display in OSL dating: An overview and some recommendations. Quat. Geochronol. 2012, 11, 1-27. [CrossRef]

51. Galbraith, R.F.; Roberts, R.G.; Laslett, G.M.; Yoshida, H.; Olley, J.M. Optical dating of single and multiple grains of quartz from Jinmium rock shelter, northern Australia: Part I, experimental design and statistical models. Archaeometry 1999, 41, 339-364. [CrossRef]

52. Guerin, G.; Mercier, N.; Adamiec, G. Dose-rate conversion factors: Update. Anc. TL 2011, 29, 5-8.

53. Brennan, B.J. Beta doses to spherical grains. Radiat. Meas. 2003, 37, 299-303. [CrossRef]

54. Prescott, J.R.; Hutton, J.T. Cosmic ray contributions to dose rates for luminescence and ESR dating: Large depths and long term variations. Radiat. Meas. 1994, 23, 497-500. [CrossRef]

55. Sanjurjo-Sánchez, J.; Barrientos Rodríguez, V. Reevaluación del potencial geotérmico de los granitos de Galicia en base a cartografía geoquímica y radiológica. Cad. Lab. Xeolóxico Laxe Rev. Xeol. Galega Hercínico Penins. 2018, 40, 123-138. [CrossRef]

56. Boyle, R.W. Geochemical Prospecting for Thorium and Uranium Deposits; Elsevier: Amsterdam, The Netherlands, 1982.

57. Gascoyne, M. Geochemistry of the actinides and their daughters. In Uranium-Series Disequilibrium: Applications to Earth, Marine, and Environmental Sciences; Ivanovich, M., Harmon, R.S., Eds.; Clarendon Press: Oxford, UK, 1992; pp. 34-62.

58. MARNA. Map of Natural Gamma Radiation of Spain. Collection; National Council of Nuclear Security (Consejo de Seguridad Nuclear): Madrid, Spain, 2000. (in Spanish) 
59. Viveen, W.; Braucher, R.; Bourlès, D.; Schoorl, J.M.; Veldkamp, A.; Van Balen, R.T.; Wallinga, J.; Fernandez-Mosquera, D.; Vidal-Romani, J.R.; Sanjurjo-Sanchez, J. A 0.65 Ma chronology and incision rate assessment of the NW Iberian Miño River terraces based on ${ }^{10}$ Be and luminescence dating. Glob. Planet. Chang. 2012, 94-95, 82-100. [CrossRef]

60. Reimer, P.J.; Austin, W.E.; Bard, E.; Bayliss, A.; Blackwell, P.G.; Ramsey, C.B.; Talamo, S. The IntCal20 Northern Hemisphere radiocarbon age calibration curve (0-55 cal kBP). Radiocarbon 2020, 62, 725-757. [CrossRef]

61. Reimer, P.J.; Brown, T.A.; Reimer, R.W. Discussion: Reporting and calibration of post-bomb 14C data. Radiocarbon 2004, 46, 1299-1304.

62. Eriksson, L. Introduction to Multi- and Megavariate Data Analysis Using Projection Methods (PCA and PLS); Umetrics AB: Umea, Sweden, 1999.

63. Abdi, H.; Williams, L.J. Principal component analysis. Wiley Interdiscip. Rev. Comput. Stat. 2010, 2, 433-459. [CrossRef]

64. Blaauw, M. Methods and code for 'classical' age-modelling of radiocarbon sequences. Quat. Geochronol. 2010, 5, 512-518. [CrossRef]

65. Balesdent, J.; Mariotti, A. Natural 13C abundance as a tracer for studies of soil organic matter dynamics. Soil Biol. Biochem. 1987, 19, 25-30. [CrossRef]

66. Koerner, W.; Dambrine, E.; Dupouey, J.L.; Benoit, M. $\delta^{15} \mathrm{~N}$ of forest soil and understorey vegeta-tion reflect the former agricultural land use. Oecologia 1999, 121, 421-425. [CrossRef]

67. Choi, W.J.; Ro, H.M.; Hobbie, E.A. Patterns of natural N-15 in soils and plants from chemically and organically fertilized uplands. Soil Biol. Biochem. 2003, 35, 1493-1500. [CrossRef]

68. Senbayram, M.; Dixon, L.; Goulding, K.W.T.; Bol, R. Long-term influence of manure and mineral nitrogen applications on plant and soil d15N and d13C values from the Broadbalk Wheat Experiment. Rapid Commun. Mass Spectrom. 2008, 22, 1735-1740. [CrossRef]

69. Taboada, T.; Martínez-Cortizas, A.; García, C.; García-Rodeja, E. Particle-size fractionation of titanium and zirconium during weathering and pedogenesis of granitic rocks in NW Spain. Geoderma 2006, 131, 218-236. [CrossRef]

70. Taboada, T.; Martínez-Cortizas, A.; García, C.; García-Rodeja, E. Uranium and thorium in weathering and pedogenetic profiles developed on granitic rocks from NW Spain. Sci. Total Environ. 2006, 356, 192-206. [CrossRef]

71. Fernández-Pompa, F.; Chamón Cobos, C.; Piles Mateo, E.; Estevez González, C.; Arce Duarte, M. Mapa geológico de la Hoja nº 226 (Allariz). In Mapa Geológico de España E. 1:50.000. Segunda Serie (MAGNA), 1st ed.; IGME: Madrid, Spain, 1972.

72. Arce, J.; Boquera, J.; Chamón Cobos, C.; Estévez González, C.; Fernández-Pompa, F.; Piles Mateo, E. Memoria de la Hoja n 226 (Allariz). In Mapa Geológico de España E. 1:50.000. Segunda Serie (MAGNA), 1st ed.; IGME: Madrid, Spain, 1974.

73. García Quintela, M. La construcción del paisaje cristiano de Galicia: Hacia la definición de un modelo de transformación. Estud. Quat./Quat. Stud. 2015, 12, 143-159. [CrossRef]

74. Blanco-Rotea, R.; García Rodríguez, S.; Mato-Fresán, C.; Sanjurjo-Sánchez, J. La Basílica da Ascensión y Os Fornos (Allariz, Ourense) y la cristianización de la arquitectura en la Antigüedad Tardía. Quat. Est. 2015, 12, 111-132. [CrossRef]

75. Curran, J. Pagan City and Christian Capital. Rome in the Fourth Century; Clarendon Press: Oxford, UK, 2000.

76. Haas, C. Alexandria in Late Antiquity. Topography and Social Conflict; The Johns Hopkins U.P.: Baltimore, UK; London, UK, 1996.

77. Deliyannis, D.M. Ravenna in Late Antiquity; Cambridge University Press: Cambridge, UK, 2010.

78. Trombley, F.R. Paganism in the Greek World at the End of antiquity. The case of Rural Anatolia and Greece. Harv. Theol. Rev. 1985, 78, 327-352. [CrossRef]

79. Nixon, L. Making a Landscape Sacred: Outlying Churches and Icon Stands in Sphakia, Southwestern Crete; Oxbow: Oxford, UK, 2006.

80. Turner, S. Making a Christian Landscape. The Countryside in Early-Medieval Cornwall, Devon and Wessex; University of Exeter Press: Exeter, UK, 2006.

81. Codou, Y.; Colin, M.-G.; Le Nézet-Célestin, M. La christianisation des campagnes (IVe -VIIIe s.). Gallia 2007, 64, 57-83. [CrossRef]

82. Andrén, A. The significance of places: The Christianization of Scandinavia from a spatial point of view. World Archaeol. 2013, 45, 27-45. [CrossRef]

83. García Quintela, M.V.; Sánchez-Pardo, J.C. Landscape, Christianisation and social power in late antique and early medieval Galicia. In Sacred Landscapes in Antiquity: Creation, Transformation and Manipulation; Haussler, R., Chiai, G.F., Eds.; Oxbow: Oxford, UK, 2020; pp. 179-193.

84. Sánchez-Pardo, J.C.; García Quintela, M.V. Ecclesiastical Landscapes in Early Medieval Galicia: Physical and Symbolic Transformations. In Ecclesiastical Landscapes in Medieval Europe: A Comparative Approach; Sánchez-Pardo, J.C., Marron, E., Tiplic, M.E., Eds.; Archaeopress: Oxford, UK, 2020; pp. 182-196.

85. Amado Rolán, N.; Blanco-Rotea, R.; García Rodríguez, S. La colegiata de Santa María a Real de Xunquiera de Ambía: La recuperación de su pazo prioral. Cuad. Estud. Gallegos 2008, 121, 139-172. [CrossRef]

86. Pifczyk, S.; Gębala, M.; Deryło, A.; Chyż, B. The Map of Holy Places in Europe. Available online: https://biqdata.wyborcza.pl/ biqdata/7,159116,22172206, the-map-of-holy-places-in-europe.html (accessed on 1 August 2021).

87. Ballesteros Arias, P.; Criado Boado, F.; Andrade Cernadas, J. Formas y fechas de un paisaje agrario de época medieval: A cidade da Cultura en Santiago de Compostela. Rev. Arqueol. Espac. 2006, 26, $193-225$.

88. Ballesteros Arias, P.; Blanco-Rotea, R. Aldeas y espacios agrarios altomedievales en Galicia. In The Archaeology of Early Medieval Villages in Europe, Documentos de Arqueología e Historia; Quirós Castillo, J.A., Ed.; Servicio Editorial de la Universidad del País Vasco: Bilbao, Spain, 2009; Volume 1, pp. 115-136. 
89. Ballesteros Arias, P. La arqueología rural y la construcción de un paisaje agrario medieval. El caso de Galicia. In Por una Arqueología Agraria. Perspectivas de Investigación Sobre Espacios de Cultivo en las Sociedades Medievales Hispánicas; Kirchner, H., Ed.; Archaeopress: Oxford, UK, 2010; pp. 25-39.

90. Desprat, S.; Goñi MF, S.; Loutre, M.F. Revealing climatic variability of the last three millennia in northwestern Iberia using pollen influx data. Earth Planet. Sci. Lett. 2003, 213, 63-78. [CrossRef]

91. McCormick, M.; Büntgen, U.; Cane, M.A.; Cook, E.R.; Harper, K.; Huybers, P.; Litt, T.; Manning, S.W.; Mayewski, P.A.; More, A.F.; et al. Climate change during and after the Roman Empire: Reconstructing the past from scientific and historical evidence. J. Interdiscip. Hist. 2012, 43, 169-220. [CrossRef]

92. Büntgen, U.; Myglan, V.S.; Ljungqvist, F.C.; McCormick, M.; Di Cosmo, N.; Sigl, M.; Jungclaus, J.; Wagner, S.; Krusic, P.J.; Esper, J.; et al. Cooling and societal change during the Late Antique Little Ice Age from 536 to around 660 AD. Nat. Geosci. 2016, 9, 231-236. [CrossRef]

93. Criado Boado and González-Pérez, C. Diseño Conceptual del Incipit. 2011. Available online: https://digital.csic.es/handle/1026 1/38172 (accessed on 1 August 2021).

94. Sánchez, P. Territorio y Poblamiento en Galicia Entre la Antigüedad y la Plena Edad Media. Ph.D. Thesis, Universidad de Santiago de Compostela, Santiago, Spain, 2008.

95. Martínez-Cortizas, A.; Pontevedra-Pombal, X.; Garcia-Rodeja, E.; Novoa-Munoz, J.C.; Shotyk, W. Mercury in a Spanish peat bog: Archive of climate change and atmospheric metal deposition. Science 1999, 284, 939-942. [CrossRef]

96. Lebreiro, S.M.; Francés, G.; Abrantes, F.F.G.; Diz, P.; Bartels-Jónsdóttir, H.B.; Stroynowski, Z.N.; Gil, I.M.; Pena, L.D.; Rodrigues, T.; Jones, P.D.; et al. Climate change and coastal hydrographic response along the Atlantic Iberian margin (Tagus Prodelta and Muros Ría) during the last two millennia. Holocene 2006, 16, 1003-1015. [CrossRef]

97. Kaal, J.; Criado-Boado, F.; Costa-Casais, M.; López-Sáez, J.A.; López-Merino, L.; Mighall, T.; Carrión, Y.; Silva-Sánchez, N.; Martínez-Cortizas, A. Prehistoric land use at an archaeological hot-spot (the rock art park of Campo Lameiro, NW Spain) inferred from charcoal, synan-thropic pollen and non-pollen palynomorph proxies. J. Archaeol. Sci. 2013, 40, 1518-1527. [CrossRef]

98. Martínez-Cortizas, A.; Mighall, T.; Pontevedra Pombal, X.P.; Nóvoa Muñoz, J.; Peiteado Varela, E.P.; Perez Rebolo, R.P. Linking changes in atmospheric dust deposition, vegetation change and human activities in northwest Spain during the last 5300 years. Holocene 2005, 15, 698-706. [CrossRef]

99. López-Merino, L.; Sánchez, N.S.; Kaal, J.; López-Sáez, J.A.; Cortizas, A.M. Post-disturbance vegetation dynamics during the Late Pleistocene and the Holocene: An example from NW Iberia. Glob. Planet. Chang. 2012, 92, 58-70. [CrossRef]

100. Bür Mier, M.; Fernández Fernández, J.; Alonso González, P. The Investigation of Currently Inhabited Villages of Medieval Origin: Agrarian Archaeology in Asturias (Spain). Quat. Int. 2014, 346, 41-55. [CrossRef]

101. Quirós Castillo, J.A.; Nicosia, C.; Polo-Díaz, A.; del Árbol, M.R. Agrarian archaeology in northern Iberia: Geoarchaeology and early medieval land use. Quat. Int. 2014, 346, 56-68. [CrossRef]

102. Quirós Castillo, J.A. Oltre la frammentazione postprocessualista. Archeologia agraria nel Nordovest della Spagna. Archeol. Mediev. 2014, 41, 23-38.

103. Fernández-Fernández, J. The archaeology of a medieval village and its agricultural area: Villanueva de Santo Adriano (Asturias, Northwest of the Iberian Peninsula). Historia Agraria. 2017, 72, 79-107.

104. Balboa López, X.L. El fuego en la historia de los montes gallegos: De las rozas al incendio forestal. In Incendios Históricos. Una Aproximación Multidisciplinar; Universidad Internacional de Andalucía: Seville, Spain, 1999; pp. 255-277.

105. Molina, F. Producción e ecoloxía do monte galego. Rev. Galega Estud. Agrar. 1979, 2, 34-35.

106. Bouhier, A. La Galice: Essai Géographique Danalyse et Dinterpretation dun Vieux Complexe Agraire; Imprimerie Yonnaise: La Roche-sur-Yon, France, 1979.

107. Pérez Rodríguez, F.J. Santa Mariña de Augas Santas en la Edad Media (ss.XI-XV). Divers. Rerum 2013, 8, $275-284$.

108. Jenkins, W.J.; Tucker, M.E.; Grim, J. (Eds.) Routledge Handbook of Religion and Ecology; Routledge: Oxfordshire, UK, 2016.

109. Ballesteros Arias, P. El Paisaje Rural Gallego. La Arqueología y la Etnografía Como Métodos de Estudio Sobre su Génesis y Transformación en el Tiempo. Ph.D. Thesis, Universidad del País Vasco, Vizcaya, Spain, 2020.

110. Sánchez Pardo, J.C.; Fernández Ferreiro, M. Monasterios familiares y espacios agrarios en la Galicia del año mil. Un estudio comparativo de los dominios de San Salvador de Bande y Santiago de Barbadelo. Studia Historica. Hist. Mediev. 2019, 37, 105-135. [CrossRef]

111. Quirós Castillo, J.A. Early medieval landscapes in north-west Spain: Local powers and communities, fifth-tenth centuries. Early Mediev. Eur. 2011, 19, 285-311. [CrossRef]

112. Aston, M. Monasteries in the Landscape; Amberley Publishing Limited: Stroud, UK, 2009.

113. Bond, J. Monastic Landscapes; Tempus Pub Ltd.: Stroud, UK, 2003.

114. Jerris, R. Cult lines and hellish mountains: The development of sacred landscape in the early medieval Alps. J. Mediev. Early Mod. Stud. 2002, 32, 85-108. [CrossRef]

115. Pestell, T. Landscapes of Monastic Foundation: The Establishment of Religious Houses in East Anglia c. 650-1200; Boydell Press: Suffolk, UK, 2004.

116. Martínez-Cortizas, A.; Ferro-Vázquez, C.; Kaal, J.; Biester, H.; Costa Casais, M.; Taboada, T.; Rodríguez-Lado, L. Bromine accumulation in acidic black colluvial soils. Geochim. Cosmochim. Acta 2016, 174, 143-155. [CrossRef] 
117. Yuita, K. Iodine, bromine and chlorine contents in soils and plants of Japan: III. Iodine, bromine and chlorine contents in the andosols and in plants of central Honshu. Soil Sci. Plant Nutr. 1983, 29, 403-428. [CrossRef]

118. Vaquero Díaz, M.B. Documentación medieval de Santa Mariña de Augas Santas no arquivo da Catedral de Ourense. Divers. Rerum 2013, 8, 251-274.

119. Grismer, M.E. Surface Runoff in Watershed Modeling-Turbulent or Laminar Flows. Hydrology 2016, 3, 18. [CrossRef]

120. Oliva, M.; Ruiz-Fernández, J.; Barriendos, M.; Benito, G.; Cuadrat, J.M.; Domínguez-Castro, F.; García-Ruiz, J.M.; Giralt, S.; Gómez-Ortiz, A.; Hernández, A.; et al. The Little Ice Age in Iberian mountains. Earth-Sci. Rev. 2018, 177, 175-208. [CrossRef]

121. Blom, P. Nature's Mutiny: How the Little Ice Age of the Long Seventeenth Century Transformed the West and Shaped the Present; Liveright Publishing: New York, NY, USA, 2019.

122. Sandoval Verea, F. O Santuario, a igrexa colexial e o Couto de Santa Mariña de Augas Santas a finais do século XVI. Divers. Rerum 2013, 8, 285-316.

123. Barriendos, M. Climatic variations in the Iberian Peninsula during the late Maunder Minimum (AD 1675-1715): An analysis of data from rogation ceremonies. Holocene 1997, 7, 105-111. [CrossRef]

124. Domínguez-Castro, F.; García-Herrera, R.; Ribera, P.; Barriendos, M. A shift in the spatial pattern of Iberian droughts during the 17th century. Clim. Past 2010, 6, 553-563. [CrossRef]

125. Saavedra, P. La Vida Cotidiana en la Galicia del Antiguo Régimen; Crítica, D.L.: Barcelona, Spain, 1994.

126. González Lopo, D.L. Mentalidad religiosa y comportamientos sociales en la Galicia atlántica (1550-1850). Obradoiro Hist. Mod. 2002, 11, 221-246. [CrossRef]

127. Madsen, A.T.; Murray, A.S. Optically stimulated luminescence dating of young sediments: A review. Geomorphology 2009, 109, 3-16. [CrossRef]

128. Ingold, T. The temporality of the landscape. World Archaeol. 1993, 25, 152-174. [CrossRef]

129. Haider, L.J.; Boonstra, W.J.; Akobirshoeva, A.; Schlüter, M. Effects of development interventions on biocultural diversity: A case study from the Pamir Mountains. Agric. Hum. Values 2020, 37, 683-697. [CrossRef] 